\title{
Tabularia
}

TABULARIA

Sources écrites des mondes normands médiévaux Les cartulaires normands. Bilan et perspectives de recherche | 2013

\section{The cartulary of the monastery of Tiron}

Le cartulaire du monastère de Tiron

\section{Kathleen Thompson}

\section{(2) OpenEdition}

\section{Journals}

\section{Electronic version}

URL: http://journals.openedition.org/tabularia/1273

DOI: $10.4000 /$ tabularia. 1273

ISSN: $1630-7364$

\section{Publisher.}

CRAHAM - Centre Michel de Boüard, Presses universitaires de Caen

\section{Electronic reference}

Kathleen Thompson, «The cartulary of the monastery of Tiron », Tabularia [Online], Les cartulaires normands. Bilan et perspectives de recherche, Online since 27 September 2013, connection on 01 May 2019. URL : http://journals.openedition.org/tabularia/1273 ; DOI : 10.4000/tabularia. 1273 


\title{
The cartulary of the monastery of Tiron
}

\section{Le cartulaire du monastère de Tiron}

\author{
Kathleen THOMPSON \\ University of Sheffield \\ k.thompson@sheffield.ac.uk
}

\begin{abstract}
:
The cartulary of the monastery of Tiron is known to scholars from an edition published in 1883 by Lucien Merlet, archivist of the département of Eure-et-Loir. New insights about its composition and purpose have been provided by a recent re-examination of the manuscript and palaeographical analysis. The cartulary was begun before 1147 and abandoned by the $1160 \mathrm{os}$. The acts are numbered and there is a $12^{\text {th }}$-century contents list, suggesting that the cartulary was intended as a records management system. Originals of some of the acts survive in the Archives départementales of Eure-et-Loir and at Winchester College in England. At the beginning of the $16^{\text {th }}$ century, the cartulary received its current binding and two gatherings were added, one written at that time and covering the Norman priory of Bacqueville-en-Caux, the other containing Pope Eugenius III's confirmation and other material dating from the $12^{\text {th }}$ century.
\end{abstract}

Keywords: Cartulary, diplomatic, palaeography, codicology, monks, records management, monasticism

Résumé:

Le cartulaire du monastère de Tiron est largement connu des historiens grâce à l'édition publiée en 1883 par l'archiviste d'Eure-et-Loir Lucien Merlet. Les analyses récentes, codicologique et paléographique, nous fournissent des précisions sur la composition et sur l'objectif visé par la réalisation de ce manuscrit. Commencé avant 1147, le cartulaire fut abandonné dans les années 1160. Les actes sont numérotés et il reste une table des matières composée au $X I{ }^{e}$ siècle. Les numéros des actes sont ajoutés à la table des matières, et cet article suggère que le cartulaire s'inscrit dans la stratégie de gestion documentaire de l'établissement. Les originaux de quelques actes sont conservés aux archives départementales d'Eure-et-Loir et au Collège de Winchester en Angleterre. Au début du XVI siècle, le cartulaire reçut sa reliure actuelle et deux cahiers furent ajoutés. L'un réalisé à l'époque, contient des actes du prieuré normand de Bacqueville-en-Caux et l'autre comprend l'acte de confirmation du pape, Eugène III, ainsi que les autres actes $d u X I I^{e}$ siècle.

Mots-clés: cartulaire, diplomatique, paléographie, codicologie, moines, archives, monachisme

Tabularia «Études», $\mathrm{n}^{\circ}$ 13, 2013, p. 65-123, 27 septembre 2013 http://www.unicaen.fr/mrsh/craham/revue/tabularia/print.php?dossier=dossier9\&file=07thompson.xml 
The monastery of Tiron was founded in the $1100 \mathrm{~s}^{1}$. The precise date of its foundation is unclear, but the life of the founder, Vita Beati Bernardi Tironiensis (BHL 1251) indicates that the first mass was held at a wooden church on Easter day ( 25 April) $1109^{2}$. It is the foundation narrative presented in the vita that has always dominated the Tironensian studies, but it needs to be supplemented by a substantial surviving archive, among which is a cartulary or record book, compiled in the $12^{\text {th }}$ century ${ }^{3}$. After the suppression of the house, it was transferred to the Archives départementales d'Eure-et-Loir at Chartres, where it received the shelf mark $\mathrm{H} 1374^{4}$. A complete copy of the cartulary ( $\mathrm{H}$ 1375) was made in the $17^{\text {th }}$ century, probably by the Maurists after they took over Tiron in $1629^{5}$.

The printed edition of the cartulary, Cartulaire de l'abbaye de la SainteTrinité de Tiron by Lucien Merlet (1827-1898), the archivist of the Eure-et-Loir, would not satisfy modern critical standards ${ }^{6}$. Merlet rearranged the entries into a chronological order determined by himself, did not publish all the acts, and included material not in the cartulary. It is, in fact, more appropriate to describe his edition as a selective archival history, but his work has been influential and has provided the main outline history of the community. A recent analysis of the manuscript has suggested new insights into the composition and purpose of the cartulary. Those insights are presented here, beginning with a physical description of the manuscript and followed by discussion of the cartulary's contents and composition. Conclusions are then drawn about the date of composition.

\section{The Manuscript of the Tiron Cartulary}

\section{Physical Description}

The codex, as it currently exists, measures approximately $200 \times 290 \mathrm{~mm}$. It consists of 97 leaves in a parchment binding, normally described as limp vellum binding. The parchment gatherings are attached to the binding with four binding tapes, threaded into the cover. The letter A appears on front and back of the cartulary and there is a blot of red ink on the front cover, which is of similar colour to the red ink of the pagination. An act of medieval date performs the role of endpapers and two pieces of paper in a $17^{\text {th }}$-century hand

1. The author is grateful to Dr Teresa Webber of Trinity College Cambridge for kindly undertaking a palaeographical analysis of the cartulary; to Professor David Bates for his advice, and to the archivist and staff of the Archives départementales d'Eure-et-Loir at Chartres for their unfailing helpfulness. The illustrations appear by kind permission of the Conseil Général d'Eure-et-Loir.

2. Grossus, 1844-1865, cols 1367-1446, at col. 1408-1409. There is no history of the Order of Tiron. Modern work includes Guillemin, 1999 and Thompson, 2009. The modern place-name is Thiron, but the abbey and the order are conventionally spelt Tiron.

3. The bibliography on cartularies is extensive. Important studies are PARISSE, 1993; Chastang, 2006; Guyotjeannin and Morelle, 2007.

4. Chartres, Arch. dép. Eure-et-Loir, H 1374.

5. Martène, 1928-1954, i, p. 265-267. On similar events at Mont Saint-Michel, Keats-Rohan, 2006, p. 4-5.

6. MerLet, 1854 
are also tipped in. There is evidence of water damage on the part of the medieval act that forms the front endpaper and its shape has been outlined by a hand of unknown date, which has created from it the whimsy of a bull's head. The parchment is not of the highest quality; there are examples of the text being arranged around holes (fol. LXXIIII, LXXVI) and of there not being enough parchment for a squared off page; fol. XXXVI and LXII are good examples of the latter. Half a leaf has been cut out at fol. LXXV.

\section{Gatherings}

The 97 leaves of the codex include some single sheets, but are mostly bifolia, arranged in quaternions ${ }^{7}$. There are four sheets of preliminaries, including a contents list, followed by 13 gatherings (see Appendix 1). At the end of the eighth gathering (fol. LXIIIv) there is a note in a $16^{\text {th }}$-century hand, indicating that a folio is missing: deesse hic unum folium, and the next gathering that begins with fol. LXIIII is made up of only six leaves in three bifolia. The twelfth gathering is made up of four leaves; two loose and a bifolium. It is not sewn into the codex, but there is a stub where it might be attached.

There are two sets of signatures - medieval [i-xi], which appears at the bottom of the last verso of the gathering, and post-medieval [i-xiij], where the signature appears at the top of the first leaf of the gathering. The post-medieval signatures begin with i on page 3 , the third page of the contents. They appear in sequence, except that the signature $\mathrm{x}$ is written on fol. XXxxVI [86], the four leaf gathering that is not sewn into the codex.

\section{Foliation and Pagination}

The codex has been foliated in roman numerals, probably in the $16^{\text {th }}$ century, with the fifth leaf as fol. I. It was later paginated in red ink, using arabic numerals, possibly in the $18^{\text {th }}$ century, with the recto of first leaf as page 1 . Both the foliation and the pagination treat the loose gathering as the twelfth gathering.

\section{Numeration}

The acts have been numbered twice, once in roman, and a second time in red ink in arabic numerals, probably by the same hand that paginated. The roman numeration is incomplete and ceases at act number ccxxxii [arabic $n^{\circ} 244$ ] on fol. LXV, but the arabic numeration continues throughout the volume, ending with number 325 on fol. IIIIxxXIII [93]v. Acts are cited in this paper using the arabic number, unless it is also appropriate to refer to the roman numeration.

7. Répertoire des cartulaires médiévaux et modernes, published by TELMA (Traitement électronique des manuscrits et des archives), prefers to describe the cartulary as having 93 leaves, with a separate four-leaf gathering written at a later date, http://www.cn-telma.fr/cartulR/codic04945/?para=3002t19 
The roman numeration took place before the folio was lost, since four roman numbers are missing from the text, but indicated in the contents list $\left(\mathrm{n}^{\text {os }} \mathrm{ccxxiiii}\right.$, ccxxv, ccxxvi and ccxxvii). The arabic numeration took place after the folio was lost, since it takes no account of the lost folio, and moves from act $\mathrm{n}^{\circ} 240$ on fol. LXIIIv to act $\mathrm{n}^{\circ} 241 \mathrm{on}$ fol. LXIIII, assigning no number to the incomplete act between them.

At the beginning of the tenth gathering (fol. LXX) the text ceases to align with the contents list. The contents pages lead us to expect Asnières ${ }^{8}$, Ferrières ${ }^{9}$ and Reuzé ${ }^{10}$, houses in northern Poitou or southern Anjou, but the text covers Bréau $^{11}$, Coutures ${ }^{12}$ and Tournan ${ }^{13}$ (acts numbered 257-284). The material on Asnières, Ferrières and Reuzé (acts numbered 285-311) actually appears in the eleventh gathering, which begins on fol. LXXVIII, but at the end of that gathering the medieval signature $\mathrm{x}$ can be seen on fol. IIIIxxV [85]. The current eleventh gathering was therefore intended to be the tenth, as the contents list indicates, so the eleventh and tenth gatherings have been transposed. This transposition of gatherings is not the only reason for the lack of alignment between the current text and the contents list, however. There has also been transposition within one of the gatherings. The contents list ends with the acts relating to Charencey ${ }^{14}$ $\left(\mathrm{n}^{\text {os }} 274-276\right)$, indicating that the original plan for the cartulary was to end there. These acts appear on fol. LXXIIIIv and there is a medieval signature mark xi at the bottom of this page, showing that it was intended to be the last page of the eleventh medieval gathering. Yet the gathering as currently constituted does not end until fol. LXXVII. If, however, the central bifolio of the gathering (fol. LXXIII and LXXIIII) were to be removed and repositioned as the outer bifolio, then the medieval signature would appear at the end of the gathering and the contents of that gathering would align perfectly with the contents list.

We can thus surmise the following sequence of events over a number of centuries: drafting, roman numeration (not completed), twelfth and thirteenth gatherings added, foliation, pagination and arabic numeration. It is not clear where within this sequence of events the binding took place. It is possible that, although gatherings $i$ to xi were given signature numbers by a $12^{\text {th }}$-century hand, they remained unbound or were given a more temporary form of limp binding. If that happened, it would have been possible, at any time before the leaves were foliated, for a single bifolio to have been lost from the ninth gathering, and for another bifolio to have been removed from its position on the outside of what is now the tenth gathering and placed in the centre of that gathering. It would also have been possible for gatherings ten and eleven to have been transposed. The post-medieval signatures suggest that a re-binding was proposed, but never

8. Dép. Maine-et-Loire, cant. Montreuil-Bellay, c. Cizay-la-Madeleine.

9. Dép. Deux-Sèvres, cant. Argenton-les-Vallées, c. Bouillé-Loretz.

10. Dép. Vienne, cant. Lencloître, c. Orches

11. Dép. Seine-et-Marne, cant. Mormant.

12. Dép. Loiret, cant. Pithiviers, c. Mareau-aux-Bois.

13. Tournan[-en-Brie], dép. Seine-et-Marne, chef-lieu de cant.

14. Dép. Orne, cant. Tourouvre. 
undertaken. This proposed re-binding would have placed the loose twelfth gathering between the existing ninth and tenth gatherings.

Lucien Merlet suggested that the monks originally had only 72 leaves, thinking this enough to cover their French and Anglo-Norman holdings. He bases his argument on the ending of roman numeration on fol. LXV and the "lack of order" [absence d'ordre] in the closing folios of the cartulary, which he describes as "higgledy-piggedly" [un peu pêle-mêle $]^{15}$. It is an intriguing argument, but it is flawed. The original order of the cartulary is plainly laid down by the contents list and it included a section on holdings to the south of the Loire and east of Paris. Although there is a haphazard quality to the arrangement of the acts, it has been caused by the transpositions of and within gatherings.

\section{Rubrication}

Rubrication begins at the bottom of fol. IIv with a description of the first act on fol. III. In this case the wording of the rubric does not match the contents list, but most rubrics do mirror the contents list. A series of small headings, which appear at the extreme outer margins from fol. IX, presumably act as place-markers for the rubricist. The rubric usually shares the first line of each act. Sometimes this approach breaks down and the rubric shares the last line of the previous act. Occasionally the rubrics appear as headings in the margin. In the thirteenth gathering there is only one rubricated heading. Initial letters are picked out in red from fol. I. Sometimes they have been omitted, although a space has been left for them. Occasionally there is an error, most notably on fol. XLVIIIv, where a red V has been added but not used and the letter $\mathrm{N}$ has been added by the scribe between the arms of the $\mathrm{V}$.

\section{Contents of the text}

There is no explanatory preface or introduction to the cartulary and the codex begins with a three-leaf contents list in double columns that covers the contents of the first eleven gatherings. The text begins on the fifth leaf and from that point the contents are entered in a single column of up to 33 lines. The earliest dated item in the cartulary is an act of Bishop Ivo of Chartres, made in 1114, and the latest is dated 21 June $1401^{16}$. Most of the acts are undated, however. The majority were written into the cartulary in $12^{\text {th }}$ century and subsequently other acts were added. There are seven of $13^{\text {th }}$-century date and one of $15^{\text {th }}$ century date. There is the four-leaf twelfth gathering, which was probably written in the early $16^{\text {th }}$ century and two entries that seem to be contemporary with it, as well as two acts in a different hand of the $15^{\text {th }}$ or early $16^{\text {th }}$ century. Short sections of each act in the text have been underlined. This underlining occurs throughout

15. Merlet, 1883, t. 1, "Introduction", p. cxiv.

16. Merlet, 1883, t. 1, p. 1-2 (I); t. 2, p. 208-209 (CCCCXII). 
the text, including the loose twelfth gathering, which indicates a post-medieval date for the underlining process.

A list of the acts in the cartulary can be found in Appendix 2. The first entries in the cartulary are papal, episcopal and comital acts. Thereafter the cartulary brings together acts relating to specific possessions. For some communities, there is only one act, while for others there are many more. There are, for example, four acts relating to the house at Saintry ${ }^{17}$ and thirteen acts relating to Villandon ${ }^{18}$. Sometimes, but not always, the acts are entered in reverse chronological order, as if the scribe had picked up a pile of single sheet acts and started to copy them from the newest act which was at the top of the pile. The acts relating to the property at Choudri ${ }^{19}$ begin with William of Plessis' confirmation of his father's benefactions, two other acts follow, and the notice of the act of William's father, which must be the earliest, is entered as the last of the acts relating to Choudri.

The arrangement of possessions is broadly topographical, but it does not follow dioceses, as did for example the Liber cartarum domus Savigneii ${ }^{20}$. From fol. VII to fol. XIv there are acts relating to the property situated closest to the mother house at Tiron. A section on property in or near Chartres begins on fol. XII and also covers the possessions of the priories of Oisème, Villandon, Ablis and Augerville. From fol. XXIIII the text is devoted to property in and around Châteaudun ${ }^{21}$. Most of this property is in the modern départements of Eure-et-Loir and Loir-et-Cher, and in the $12^{\text {th }}$ century this area was in the power of the Thibaudian counts of Blois/Chartres. There is a similar quasi-political dimension to the section of the cartulary beginning on fol. XLVIII, which starts with the heading Incipiunt cartula de partibus normannie siue anglie. It contains the privileges of the kings of England and dukes of Normandy, as well as to gifts by Scottish rulers and important Anglo-Norman nobles, and it is followed by Angevin and Poitevin material. On fol. LXI there are acts by kings, Louis VI and King Louis VII, and then a section begins on houses situated in lands under the influence of the Capetian family. As we have seen, gatherings 10 and 11 are transposed in the current binding, so it was intended that the cartulary would treat houses to the south of the Loire, such as Asnières, Ferrières and Reuzé, before those now covered in gathering 10, Bréau, Couture, and Tournan. These eleven gatherings are reflected in the contents pages.

The four-leaf twelfth gathering contains acts relating to the priory of Bacqueville ${ }^{22}$ and is written in an archaising hand, probably of the $15^{\text {th }}$ or early $16^{\text {th }}$ century. The thirteenth and final gathering from fol. IIIIxxX [90] records a version of the bull of Pope Eugenius III and properties in modern

17. Dép. Loiret, cant. Meung-sur-Loire, c. Épieds-en-Beauce.

18. Probably dép. Eure-et-Loir, cant. Voves, c. Montainville, where there are modern placenames of Andeville and Viabon.

19. Dép. Loir-et-Cher, cant. Ozouer-le-Marché, c. Pré-Nouvelon.

20. Poulle, 1996, p. 115 .

21. Dép. Eure-et-Loir, chef-lieu de cant.

22. Bacqueville[-en-Caux], dép. Seine-Maritime, chef-lieu de cant. 
Seine-et-Marne, Sarthe, Mayenne and Ille-et-Vilaine, written in hands that did not contribute to the earlier sections of the cartulary.

Most of the acts in the cartulary are notices and there are fewer than twenty formal charters beginning Ego or an invocation and Ego in the cartulary, but many of the notices contain the word ego, suggesting that they have been adapted from formal charters. A number of the entries, which relate gifts to a single Tironensian community or to the gifts of an individual, can be described as pancartes; they are probably copies of documents with a commemorative liturgical significance and often begin with a preamble about the transience of human life ${ }^{23}$. There are some chirographs and one example of a list of rents.

Some acts survive as single sheet documents; they are held by the archives at Chartres and by Winchester College, which bought the English property of the monastery of Tiron in $1391^{24}$. It is therefore possible to check the cartularists' work; orthography can vary - Gosfredus to Gaufridus, for example, suggesting generational differences between scribes, but the transcription is generally accurate, if sometimes abbreviated in, for example, the address clauses ${ }^{25}$. A notable exception to this general level of accuracy, however, is the cartulary's version of Pope Eugenius III's confirmation ${ }^{26}$. Comparison between the original and the cartulary indicates that the cartulary version of Eugenius' act rearranges the properties for confirmation according to diocese, while the original version retained an element of seniority of foundation.

In short, then, the purpose of the cartulary was descriptive rather than historical. There is no underlying narrative to the work and the cartularists copied the material available to them in a geographical, rather than chronological order, seldom making anything other than minor changes to the text of the documents that were copied.

\section{Composition of the text}

A palaeographical analysis has been kindly provided by Dr Teresa Webber, which is incorporated in Appendix 2. The analysis indicates that more than twenty hands can be discerned in the cartulary text as it currently stands. This does not mean that more than twenty scribes were involved in its composition; some scribes may be writing in a different style, but it is not possible to be certain on palaeographical grounds. There are two main scribes, A and B, both working towards the second half of the $12^{\text {th }}$ century. Their hands are interspersed with those of other scribes and indeed with each others'. These two scribes undertook concentrated

23. Pancartes monastiques des XI et XII e siècles, PARIsse, PÉGeot et Tock, 1998, reviewed by Guyotjeannin, 2000.

24. Inventaire sommaire des Archives départementales antérieures à 1790, Eure-et-Loir: archives ecclésiastiques, série H, p. 157-207; HimsworTH, 1976-1984. Documents held by Winchester College will be prefixed WCM. Surviving single sheet acts are: Arch. dép. Eure-et-Loir, H 1378; H 1405; H 1419; H 1514; H 1577; H 1579; H 1737; WCM 4268a; WCM 10625, 10627, 18928.

25. On changes in orthography, BOuCHARD, 2002, p. 32.

26. Merlet, 1883, t. 2, p. 60-66 (CXCI, CXCII). 
writing campaigns and their work is likely, on stylistic grounds, to have been simultaneous. Between them they wrote most of the first eleven gatherings, but made no contribution to the twelfth or thirteenth gatherings. In terms of content, Scribe A wrote the contents list, the home endowment, lands in the Chartrain and Beauce, from Châteaudun down to Blois and into the Vendômois; Scribe B's hand predominates from fol. XXXII to the end of the eleventh gathering, with the exception of the ninth gathering, which was mostly written by Scribe A.

A likely scenario therefore is that Scribe A began work first, making a copy of all the monastery's records concerning the "home" endowment around the mother house. When that was complete he turned his attention to the community's holdings at Chartres. As he continued this task the potential of his work as a tool for the oversight of all the monks' property became apparent, and it was decided to expand its coverage. Scribe A made copies of acts from more distant Tironensian communities, such as Hamble ${ }^{27}$ or Sept-Faux ${ }^{28}$. Then Scribe B joined the project and took over responsibility for the distant Tironensian communities, so his writing surrounds Scribe A's original entries for these distant houses. (See illustration 1). Dr Webber's analysis has identified a point in act $n^{\circ} 254$ on fol. LXIXr, where Scribe A has stopped work and another scribe has completed the act. The hand of this second scribe displays some similarities with that of Scribe B, but lacks his consistency. Dr Webber notes, however, similar lapses, in the hand that wrote fol. LXXIIr and on fol. IIII ${ }^{\mathrm{XX}} \mathrm{IIIr}$. Perhaps this is Scribe B's early work on the cartulary, written before his characteristic style developed and while he was working under the supervision of Scribe A.

By the point, when Scribe A was joined by his colleague, however, he had probably become aware of some disadvantages in the work he had already done. When he started, he had left no space for new benefactions or additions to existing ones. As a result, substantial rewriting had been necessary; at fol. IX, for example, as act $n^{\circ} 31$ continues from fol. VIIIv onto the new gathering, the hand changes. This new hand wrote the next three leaves, before Scribe A's hand resumes. It is possible that this was written by another scribe, but it may be Scribe A writing to a different scale to accommodate more material. To ensure that new material could be incorporated, therefore, when Scribe B began work, he was probably encouraged to leave space for additions and thus he began acts at the bottom of leaves. (See illustration 2)

So we can see the two scribes at work on the cartulary, with Scribe A as the senior partner. In the ninth gathering, however, Scribe A seems to falter. He had entered material related to the Tironensian community at Le Gué de Launay ${ }^{29}$ and, when he had finished, in line with his normal practice, he left some space (fol. LXVv). The next folio is headed de cruce uallis, and the contents list also leads us to expect that acts about Croixval ${ }^{30}$ will follow those on Le Gué de Launay, but

\footnotetext{
27. Hamble-le-Rice, Hampshire, England ( ${ }^{\circ}{ }^{179}$, fol. XLVIIIv).

28. Dép. Loire-Atlantique, cant. Le Pellerin, c. Vue ( ${ }^{\circ} 306$, fol. LXXXIIIv).

29. Dép. Sarthe, cant. Vibraye.

30. Dép. Loir-et-Cher, cant. Montoire-sur-le-Loir, c. Ternay.
} 
that is not the case. Here, Scribe A wrote an act ( $\left.n^{\circ} 245\right)$ relating to the community at Tourny, also known as La Théroudière ${ }^{31}$, despite the fact that the other acts relating to Tourny can be found elsewhere ${ }^{32}$. It is significant that it is at this point that the roman numeration of the cartulary ceased. The numerator was perhaps uncertain how to handle the error that he had discovered and numbered no further. There is material relating to Croixval, which begins on fol. LXVIv and finishes on fol. LXVII, and it is in Scribe A's hand; perhaps he had already written it, when he mistakenly entered the Tourny act. He also wrote acts $n^{\circ} 249-53$ and began to enter act $n^{\circ} 254$, but he did not complete it. Scribe B completed the ninth gathering and was responsible for entering the majority of the acts in the tenth and eleventh gatherings, which concluded the planned contents of the cartulary as described in the contents list.

The twelfth and thirteenth gatherings were not part of the cartulary as described in the contents list. The four-leaf twelfth gathering contains acts relating to the priory of Bacqueville in Normandy. Stein took the view that these leaves date from the $15^{\text {th }}$ century and come from a lost cartulary of the abbey, while Lucien Merlet thought that they were written in the $16^{\text {th }}$ century. Although there is some evidence of the existence of a lost cartulary in the $17^{\text {th }}$ century ${ }^{33}$, the twelfth gathering cannot have formed part of it, because the twelfth gathering was foliated along with the rest of the cartulary in the late $15^{\text {th }}$ or early $16^{\text {th }}$ century.

\section{The date of the cartulary and conclusions}

The absence of Eugenius III's confirmation of 1147 from the papal acts copied into the beginning of the cartulary suggests that the early leaves of the cartulary were written before Eugenius' act was received in the house and thus that work had begun by the 1140 . There are a number of acts dated to the 1140s in scribe A's hand $\left(\mathrm{n}^{\text {os }} 12,50,128,130\right)$ but none that can be securely dated to the 1150 . Indeed, with the exception of the Anglo-Norman material, there is little in the cartulary that can be dated to the 1150 s at and very little beyond that date. The archives at Chartres, however, contain Tironensian acts from the later $12^{\text {th }}$ century that were not copied into the cartulary, the earliest of which can be dated to $1166^{34}$.

Dr Webber's palaeographical analysis and that of the $19^{\text {th }}$-century editor, Lucien Merlet, point towards composition in the 1160 os or $1170 \mathrm{~s}^{35}$. Contents

31. Dép. Eure, cant. Écos.

32. Fol. LVI ( $\left.{ }^{\text {os }} 213-215\right)$.

33. In 1608, Henri IV of France assigned the Tironensian priory of Bacqueville to the Jesuit college at Rouen, Merlet, 1883, t. 2, p. 247 (CCCCXXIII). The Jesuits then arranged for Jacques Marion, the notary public at Thiron, to make certified copies of the Tironensian documents that proved Bacqueville's title to property. Six of the acts Marion copied were taken from the old cartulary (vieulx cartulaire), and the folio numbers match those of the twelfth gathering of the cartulary. He copied four other acts from a paper volume (d'un vieux livre estant en papier sans couverture nomme l'un des vieux cartulaire de l'abbaye de Thiron folio trente quatre, trente six \& trente sept), Rouen, Arch. dép. Seine-Maritime, H 195-7.

34. Chartres, Arch. dép. Eure-et-Loir, H 1469, records the gift of Matthew of Frileuse and is dated 1166.

35. Merlet, 1883, t. 1, "Introduction”, p. cxi. 
analysis, however, suggests that the cartulary was begun in the 1140s and was nearly complete by the 1160 s. In support of this dating, there is evidence to be drawn from the date of the roman numeration, which was no earlier than 1156 . Act ${ }^{\circ} 232$ (roman $n^{\circ}$ ccxvi), which is dated 1156, was inserted by Scribe 2 into Scribe B's existing text and that insertion took place exactly when the numeration was in progress (see illustration 3). Details of this late arrival were added to the margin of the contents page by the numerator, and the act was given the next number in the sequence. Thus act $\mathrm{n}^{\circ} 232$ must have been added while the numeration was taking place (See illustration 4).

Michel Parisse identifies two main occasions for the decision to compile a cartulary: the installation of a new head of the community or a response to a period of confusion or external challenge ${ }^{36}$. We do not know when Tiron's long-serving Abbot William was succeeded by another abbot, nor indeed are we certain who that abbot was. William was still in office when Pope Eugenius issued his confirmation in 1147 , however, so the cartulary is unlikely to have been the initiative of a new abbot. Similarly there was no major crisis to prompt an overhaul of the monastery's record-keeping and no challenges that would encourage the development of a cartulary as a tool to justify the recovery of lost lands. In fact, the cartulary seems to have been a response to the problems of organising the records that were accumulating about an ever-increasing patrimony. It was a secure way of preserving records and it was perhaps a more efficient way of retrieving them when they were needed ${ }^{37}$. A codex format was more attractive for the record-keeper than working through bundles of single sheet records, and the importance of the ease of retrieval is demonstrated by the time invested in numbering the entries.

The volume could also act as a memorial to those who had made gifts, and many of the acts make reference to such preservation in their preambles: Quoniam humanarum rerum oblivione interveniente et morte que via est universe carnis sua jura vindicante atque dominium suum per universum orbem terrarum exercente, que fiunt sine litterarum apicibus custodiri diu nequeunt ad posterorum memoriam libet scripto annotari quod ego... is a formulation used in two acts in the cartulary and one single sheet original ${ }^{38}$.

It seems however that the community had lost interest in the cartulary by the mid 116os. Although it was completed after a fashion, and perhaps given a temporary binding, little was added to it in the $13^{\text {th }}$ and subsequent centuries. A mid $13^{\text {th }}$-century roll exists, however, which gives details of the rents due from the properties held by the monks of Tiron and this may have how they subsequently managed their property ${ }^{39}$.

36. PARISSE, 1993, p. 507.

37. DEClerQ, 2000, p. 160 .

38. For the cartulary acts, $\mathrm{n}^{\circ}$ 10, fol. IIII, printed as MERLET, 1883, t. 1, p. 70 (L) and $\mathrm{n}^{\circ}{ }_{153}$, fol. XXXIX, printed as MerLet, 1883, t. 1, p. 39 (XXII), which survives as a single sheet original Chartres, Arch. dép. Eure-et-Loir, H 1514, H 1538, printed as MerLet, 1883, t. 1, p. 14 (III) survives as an original, but is not copied into the cartulary.

39. Chartres, Arch. dép. Eure-et-Loir, H 1434. 


\section{Bibliography}

BouchaRd, Constance, "Monastic cartularies: organizing eternity", in Charters, cartularies and archives: the preservation and transmission of documents in the medieval West, proceedings of the Commission internationale de diplomatique (Princeton and New York, 16-18 September 1999), Adam J. Kosto and Anders Winroth (dir.), Toronto, Pontifical Institute of Mediaeval Studies, 2002, p. 22-32.

Chastang, Pierre, "Cartulaires, cartularisation et scripturalité médiévale: la structuration d'un nouveau champ de recherche", Cahiers de civilisation médiévale, 49, 2006, p. 21-31.

DeClercQ, Georges, "Originals and cartularies: the organization of archival memory $\left(9^{\text {th }}-11^{\text {th }}\right.$ centuries)", Charters and the use of the written word in medieval society, Karl Heidecker (ed.), Turnhout, Brepols (Utrecht studies in medieval literacy, 5), 200o, p. 148-170.

Grossus, Geoffrey, "Vita Beati Bernardi Tironiensis", in Patrologia cursus completus, series Latina, ed. J.-P. MIGNE, 221 vols., Paris, Garnier, 1844-1865, CLXXII, cols 13671446.

Guillemin, Denis, Thiron, abbaye médiévale, Montrouge, Amis du Perche, 1999.

Guyotjeannin, Olivier and Morelle, Laurent, “Tradition et réception de l'acte médiéval: jalons pour un bilan des recherches", Archiv für Diplomatik, 53, 2007, p. 367-440.

Guyotjeannin, Olivier, Compte rendu de l'ouvrage Pancartes monastiques des XI ${ }^{e}$ et XII ${ }^{e}$ siècles, études reunies par Michel Parisse, Pierre PÉGeot et Benoît-Michel Tock, Turnhout, Brepols, 1998, 203 p., ill., Bibliothèque de l'École des Chartes, t. 158,2000, p. $353-354$.

Himsworth, Sheila, Winchester College muniments: a descriptive list, Chichester, Phillimore, 1976-1984, 3 vols.

Keats-Rohan, Katharine (ed.), The cartulary of the abbey of Mont Saint-Michel, Donington, Shaun Tyas, 2006.

Martène, Edmond, Histoire de la Congrégation de Saint-Maur, dom Gaston Charvin (ed.), Paris, Picard, 1928-1954, 10 vols. in 9 vols.

Merlet, Lucien (ed.), Cartulaire de l'abbaye de la Sainte-Trinité de Tiron, Chartres, Garnier, 1883, 2 vols.

Merlet, Lucien, “Chartes fausses de l'abbaye de la Trinité de Tiron”, Bibliothèque de l'École des Chartes, t. 15, 1854, p. 516-527.

MERLET, René (ed.), Inventaire-sommaire des archives départementales antérieures de 1790, Eure-et-Loir: archives ecclésiastiques, série H, Chartres, Garnier, 1897, p. 157-207.

Pancartes monastiques des XI et XII ${ }^{e}$ siècles, Table ronde organisée à l'université de Nancy II par l'ARTEM les 6 et 7 juillet 1994, Michel PARIsse, Pierre PÉGeOt et Benoît-Michel Tock (dir.), Turnhout, Brepols (Atelier de Recherche sur les Textes Médiévaux), 1998. 
PARISSE, Michel, "Les cartulaires: copies ou sources originales?", in Les cartulaires, Olivier Guyotjeannin, Laurent Morelle and Michel Parisse (dir.), Actes de la table ronde organisée par l'École nationale des Chartes et le GDR 121 du CNRS, Paris, École des Chartes, 1993, p. 503-512.

Poulle, Béatrice, "Les sources de l'histoire de l'abbaye cistercienne de Savigny au diocèse d'Avranches", Revue Mabillon, 7, 1996, p. 105-125.

Thompson, Kathleen, "The first hundred years of the Abbey of Tiron: institutionalizing the reform of the forest hermits", Anglo-Norman Studies, 31, 2009, p. 104-117.

http://www.unicaen.fr/mrsh/craham/revue/tabularia/print.php?dossier=dossier9\&file=07thompson.xml 


\section{Appendix 1: The Codex}

The Tiron cartulary (Chartres, Arch. dép. Eure-et-Loir, H 1374) is a volume of 97 leaves, constituted as follows:

\section{Preliminaries}

End paper - half an act, bound upside down

Some papers attached to a parchment stub

1 leaf of parchment sewn on a stub

1 folio with a ghostly i at top first leaf

1 parchment act sewn on a stub

\section{Gatherings Signatures and notes}

[1] $i^{8}$ folios I to VIII ij at top centre on fol. I;

medieval signature i. bottom centre on fol. VIIIv

[2] ii ${ }^{7}$ folios IX to XV iij at top centre on fol. IX;

medieval signature .ii. bottom centre on fol. XVv

Fol. XII is a single sheet

[3] iii $^{8}$ folios XVI to iiij at top centre on fol. XVI;

XXIII medieval signature iii. bottom centre on fol. XXIIIv

[4] iv ${ }^{8}$ folios XXIIII to $v$ at top centre on fol. XXIIII;

XXXI medieval signature iiii bottom centre on fol. XXXIv

[5] $\mathrm{v}^{8}$ folios XXXII to $\mathrm{vj}$ at top centre on fol. XXXII;

XXXIX medieval signature . v. bottom centre on fol. XXXIXv has

been overwritten

[6] $\mathrm{vi}^{8}$ folios XL to vij at top centre on fol. XL;

XLVII vi bottom centre on fol. XLVIIv

[7] vii ${ }^{8}$ folios XLVIII viij at top centre on fol. XLVIII;

to $\mathrm{LV}$ medieval signature vii not quite bottom centre on fol. $\mathrm{LVV}$

[8] viii ${ }^{8}$ folios LVI to ghostly ix at right top on fol. LVI;

LXIII medieval signature viii not quite bottom centre on

fol. LXIIIv

[9] $\mathrm{ix}^{6}$ folios LXIIII to $\mathrm{xj}$ at top centre on fol. LXIIII;

LXIX [medieval signature ix would have appeared on the missing folio]

[10] $\mathrm{X}^{8}$ folios LXX to faint xij at top centre on fol. LXX;

LXXVII medieval signature xi bottom centre fol. LXXIIIIv

[This is the end of the cartulary as defined in the contents list]

[11] $\mathrm{xi}^{8}$ folios LXXVIII xiij at top centre on fol. LXXVIII;

to IIIIxxV medieval signature $\mathrm{x}$ bottom centre on fol. IIII $x \mathrm{xVV}$

[Asnières gathering, in wrong place because of transposition]

[12] $\mathrm{xii}^{4}$ folios $\mathrm{XXxxVI} \quad \mathrm{x}$ at top centre on fol. $\mathrm{XXxxVI}$ to IIIIxxIX 1 leaf loose, 1 leaf loose, 2 in fol.

[13] xiii $^{4}$ folios IIIIxxX xiiij at top centre on fol. IIIIxxX, to IIIIxxIII verso 1 leaf loose, 1 leaf loose, 2 in fol.

Endpaper - the other half of the upside down act 


\section{Appendix 2: List of Acts in the Tiron Cartulary}

T1 = Merlet, 1883, t. 1. T2 = Merlet, 1883, t. 2. ADEL = Arch. dép. Eure-et-Loir

(Numbers are those of the arabic numeration)

1/ Abbot William to Bishop William of Le Mans, 1145. Loose leaf. Printed T2.40 (CCLXX).

Late medieval forgery

2/ Pope Calixtus II's act of confirmation to Tiron, 1119, fol. I. Printed T1.36 (XX).

Scribe A

3/ Pope Innocent II act of confirmation to Tiron, 1132, fol. Iv. Printed T1.201 (CLXXXII). Single sheet original, ADEL H 1378.

Scribe A

4/ Bishop Geoffrey of Chartres (1116-1149) grants church of Saint-Lubin-des-Cinq-Fonts, undated, fol. IIr. Printed T1.187.

Scribe A

5/ Bishop Geoffrey of Chartres concedes Symon of Berlanville's church of Saint-Germain of Coulonges, undated, fol. IIr. Printed T1.254 (CCXXVI).

Scribe A

6/ Bishop Ivo of Chartres (1090-1115), Dean Arnold and the chapter of Chartres concede a carrucate of land to monks of Tiron, 1114, fol. IIv. Printed T1.1 (I).

Scribe A

7/ Bishop Ivo of Chartres notifies the consecration of a cemetery for the monks of Tiron at the request of Count Rotrou, undated but before December 1115, fol. IIIr. Printed T1.13 (II).

Scribe A

8/ Bishop Geoffrey of Chartres notifies that Robert of La Motte and his son Walter have resigned the church of Saint-Lubin-des-Cinq-Fonts and the tithes of Argenvilliers, which he has assigned to the monks of Tiron, after 1132, fol. IIIr. Printed T1.188 (CLXIV).

Scribe A

9/ Bishop Geoffrey of Chartres gives to the church of Marolles to the monks of Tiron, undated, fol. IIIv. Printed T1.82 (CXCVI).

Scribe A

10/ Count Rotrou of the Perche gives to the monks of Tiron a weekly amount of salt, a tithe of his storehouses, usage of his woodlands, the holding of Arcisses, a lake, mill, valley, chapel and garden, undated but after 1116, fol. IIIIr. Printed T1.39 (XXII).

Scribe A

http://www.unicaen.fr/mrsh/craham/revue/tabularia/print.php?dossier=dossier9\&file=07thompson.xml 
11/ Count Rotrou of the Perche confirms all that he has given to the monks of Tiron at Arcisses, undated, fol. IIIIr. Printed T1.53 (XXXIII).

Scribe A

12/ Notice of the settlement of a dispute with Adeles Filoche, wife of Robert of Blainville, concerning his property near the monastery, which he gave in conuersione sua, 1141, fol. Vr. Printed T2.27 (CCLVII).

Scribe A

13/ Notice of a lease by Abbot William to Robert of Beaumont of the land of Stephen Gigul, undated but before 1144, fol. Vv. Printed T1.82 (LXII).

Scribe A

14/ Notice that Prior Bernard of Nogent-le-Rotrou conceded the tithe of Old Tiron [Veteri Tyrone] and other property to the monks of Tiron in exchange for the land of Robert Judas which he had given to both monastic communities, February 1130, fol. Vv. Printed T1.139 (CXVIII).

Scribe A

15/ Notice that Goscelin of Mongerville and William fitz William fitz Mascelinus gave the land of Malaise, undated, fol. VIr. Printed T1.159 (CXXXIII).

Scribe A

16/ Notice that Walter known as Pagan fitz Richer gave all that he held at Malaise to the monks of Tiron, 1133, fol. VIr. Printed T1.140 (CXIX).

Scribe A

17/ Notice that Lambert Bigoth gives to the abbot, church and monks of Tiron whatever he held in the vicinity of the monastery and his fee of Malaise, undated, fol. VIr. Printed T2.8o (CCCVII).

Scribe A

18/ Notice that Hugh of Rocé gives to the church and tithes of Marolles to the monks of Tiron by the hand of Bishop Geoffrey of Chartres, undated but after 1132, fol. VIv. Printed T1.226 (CXCVI).

Scribe A

19/ Count Rotrou of the Perche (1100-1144) notifies that he gave property itemised in the act to the monks of Tiron, with the approval of his mother, Beatrix, and wife, Mathilda, before 1120, fol. VIv. Printed T1.125 (CVI). This act has been written on an erasure. It is dated 1149 ( $m^{o}$.c. quadrag'. ix $x^{\circ}$ ), but this is clearly incorrect since the regnal clause is Regnante in gallia ludouico philippi . henrico anglorum rege. King Louis died in 1137 and King Henry in 1135. The act is more likely to refer to events in Lent (Quadregisma) 1109. Written by a scribe whose hand shares similarities with that of Scribe A, but there are a number of differences of detail.

Unidentified hand 1 
20/ Notice that Robert of Beaumont gives a measure of wheat at Frétigny, undated, fol. VIIr. Printed T1.83 (LXIII).

Scribe A

21/ Notice that Drogo Pichart gave a tithe he used to hold at Baionviler, undated, fol. VIIr. Printed T2.68 (CCXCIV).

Scribe A

22/ Notice that Robert of Blainville gave land across the Tiron river, undated, fol. VIIv. Printed T1.115 (XCIII).

Scribe A

23/ Notice that Robert of Blainville gave his land of Malaise, 1117, fol. VIIv. Printed $\mathrm{T} 1.23$ (XI).

Scribe A

24/ Notice that Pagan fitz Richer has given a half vineyard in Bray, undated, fol. VIIv. Printed T1.144 (CXXII).

Scribe A

25/ Notice that Robert of Courtalain gives the tithe of the mill of Marolles, undated, fol. VIIIr. Printed T1.72 (LI).

Scribe A

26/ Notice that Pagan of Villa Perdita, Pagan fitz Richer and Hameric and Ernaud of Tercé gave land in their fee of Tercé to the monks of Tiron, undated, fol. VIIIr. Printed T1.189 (CLXVI).

Scribe A

$27 /$ Notice that Walter, known as Pagan fitz Richer, gave his land at Malaise, which he held from the lady Albereda and Robert of Blainville to the monks of Tiron, 1128, fol. VIIIr. Printed T1.113 (XCI). A shorter version of $\mathrm{n}^{\circ} 16$.

Scribe A

28/ Notice that Stephen of Gardais gave to the monks of Tiron a mill site at Gardais, undated, fol. VIIIr. T1.145 (CXXIII).

Scribe A

29/ Notice that Drogo of Coutoulin gave to the monks of Tiron three arpents of meadow at Pré-Morin on account of the $£ 8$ dunois that he owed them, undated, fol. VIIIv. Printed T1.145 (CXXIV).

Scribe A

30/ Notice that Hugh of Crignon abandoned the claim he made on the monks of Tiron over the sluices of the mills of Espaus (rubric calls these the mills of Arcisses), undated, fol. VIIIv. Printed T2.2 (CCXXVIII).

Scribe A

http://www.unicaen.fr/mrsh/craham/revue/tabularia/print.php?dossier=dossier9\&file=07thompson.xml 
31/ Notice that Hugh of Boigne, his wife Osanna and children gave meadow to the monks of Tiron, undated, fol. VIIIv. Printed T1.55 (XXXIV). The gathering ends after two lines of this act and the act is continued in a different hand, which may be the same scribe, writing in a compressed style. To draw a distinction between these two styles this hand is referred to as "Unidentified hand 2".

Unidentified hand 2

32/ Notice that Odo, son of Hugh of Boinne sold the monks of Tiron three arpents of meadow for $£ 12,1130$, fol. IXr. Printed T1.142 (CXX).

Unidentified hand 2

33/ Notice that Joslen fitz Fulcher sold three arpents of meadow on the Huisne for $\mathfrak{}_{4}$ dunois, fol. IXr, undated. Printed T1.56 (XXXV).

Unidentified hand 2

34/ Notice that Arnaldus Malboverius made a settlement with his family when he wished to become a monk and conceded his share, which comprised three arpents of meadow at Pré-Morin, to the monks of Tiron, undated but before 1120, fol. IXr. Printed T1.84 (LXIV).

Unidentified hand 2

35/ Notice that Gerald of Rivray sold one arpent of meadow at Pré-Morin for 25s., undated, fol. IXv. Printed T1.94 (LXXV).

Unidentified hand 2

36/ Notice that the monks of Tiron bought an arpent of meadow at Pré-Morin for 30 . from Robert the serjeant, undated, fol. IXv. Printed T1.115 (XCIV).

Unidentified hand 2

37/ Notice that Robert Berenguarinus sold the monks of Tiron an agripennum of meadow at Pré-Morin for 32s., undated, fol. IXv. Printed T1.194 (CLXXIII).

Unidentified hand 2

38/ Notice that Geroie of Ferrières sold the monks of Tiron six arpents of meadow at Longum Pratum for 20os., undated, fol. IXv. Printed T1.116 (XCV).

Unidentified hand 2

39/ Notice that Geoffrey of Boigne exchanged the $13^{1 / 2} \mathrm{~d}$ rent formerly paid by the monks of Tiron for 15s., undated, fol. IXv. Printed T1.84 (LXV).

Unidentified hand 2

40/ Notice that Hugh of Boigne exchanged with the monks of Tiron 2 arpents of meadow at Pré-Morin, undated, fol. Xr. Printed T1.85 (LXVI).

Unidentified hand 2 
41/ Notice that Warin Capreolus gives and concedes land at Brimont to the monks of Tiron, undated, fol. Xr. Printed T1.85 (LXVII). Single sheet original ADEL H 1579 contains this and $\mathrm{n}^{\mathrm{os}} 42$ and 43 .

Unidentified hand 2

42/ Notice that William of Follet, give a carrucate of land in Brimont, undated, fol. Xr. Printed T1.245 (CCXVII). Single sheet original ADEL H 1579.

Unidentified hand 2

43/ Notice that ego, Geoffrey of Beaumont gave to the monks of Tiron a carrucate of land in Brimont, undated, fol. Xr. T1.146 (CXXV). Single sheet original ADEL H 1579.

Unidentified hand 2

44/ Notice that Odo de Virgultis, his brother-in-law, Constantius, and cousins, William and Oger of Virgultis, gave to the monks of Tiron the hunter's meadow at Daviticaria, for an annual rent of 7 d., undated, fol. Xr. Printed T2.42 (CCLXXI). Single sheet original ADEL $\mathrm{H} 1577$ has been adapted to produce this entry.

Unidentified hand 2

45/ Bishop Geoffrey of Chartres gives and concedes the church of Argenvilliers to the monks of Tiron, with the approval of the archdeacon, Goslen, undated, fol. Xv. Not printed by Merlet and appears to be an earlier version of $n^{\circ} 47$.

Scribe A

46/ Notice that Walter of Saint-Lubin gave us what he had in the tithe of Saint-Lubin, meadow at Châtaigniers and rights to timber at Saint-Lubin which he held with his brother, Robert, undated, fol. Xv. Printed T1.117 (XCVI).

Scribe A

47/ Bishop Geoffrey of Chartres gives and concedes the church of Argenvilliers to the monks of Tiron, with the approval of the archdeacon, Goslen, together with half the offerings at the Nativity, Easter and All Saints and rights to tithes, extending those he had given earlier from the fee of Robert of La Motte, undated, fol. XIr. Printed T1.10o (LXXXI).

Scribe A

48/ Bishop Geoffrey of Chartres gives and concedes to the monks of Tiron the church of Brunelles with the approval of the archdeacon, Goslen, undated, fol. XIr. Printed T1.86 (LXVIII).

Scribe $\mathrm{A}^{40}$

49/ Notice that Geroius of Lunviler, wishing to go to Jerusalem, gave to the monks of Tiron a house at Ferrières and added land there formerly held by Reginald of Ferrières

40. $\mathrm{N}^{\mathrm{os}} 47$ and 48 were probably given in the 1140 os after work on the earliest leaves of the cartulary had begun, since they are not included among the episcopal acts at the beginning of the cartulary. 
for a mark of silver in vadimonium, together with his meadows for which the monks used to pay 12d. annually, undated, fol. XIr. Printed T2.43 (CCLXXII).

Unidentified hand 2

50/ Count Rotrou of the Perche gives notice that he has conceded to Abbot William and the brothers the house of the doctor, Baldwin, at his request, and all that he held at Nogent from the count's gift, 1141, fol. XIv. Printed T2.26 (CCLVI).

Scribe A

51/ Notice that Hersendis de Curia, her son Villanus and her husband Hugh of Rotorio gave to the monks of Tiron all the meadows they used to have at Margon, undated, fol. XIv. Printed T2.44 (CCLXXIII).

Unidentified hand 3

52/ A proforma letter in the name of Brother John, abbot of Tyron (c. 1277-97) notifying a monastery (talis monasterii) of the date of the election for their new abbot, undated, fol. XIv. Printed T1.50, fn. 1.

$$
\text { Late } 13^{\text {th }} \text { - or early } 14^{\text {th }} \text {-century hand }
$$

53/ A proforma letter in the name of Brother John, abbot of Tyron notifying all the members of the Tironensian convent that an election must be held at Tiron, undated, fol. XIv. Not printed.

$$
\text { Late } 13^{\text {th }} \text { - or early } 14^{\text {th }} \text {-century hand }
$$

54/ Count Theobald of Blois notifies that he has given and conceded to the monks of Tiron in the city of Chartres six named serjeants and six named bakers, as well as the site of a mill, dated 1121 and reissued in 1138 under the authority of the count's seal, fol. XIIr. Printed T1.64 (XLV). Single sheet original ADEL H 1405.

Scribe A

55/ Notice that Abbot William and the convent of Tiron conceded their houses in the market at Chartres to Evrard the Smith and his wife and were granted Evrard's house in exchange, undated, fol. XIIr. Printed T1.44 (XXVIII).

Scribe A

56/ Notice that Heldvis wife of Glavin the butcher sold a house at Chartres to the monks of Tiron, undated, fol. XIIv. Printed T1.74 (LIII). This act is followed by a notice that Lorinus of Porta Drocensi sold land to the monks of Tiron for $48 \mathrm{~s}$., also undated. Printed T1.228 (CXCIX). Space has been left for an illuminated letter, as if this were a separate act, but the contents refers to the two acts together as De furno Carnoti et quadrata terre. See $\mathrm{n}^{\circ} 70$ for a full version of this act.

Scribe A

57/ Notice that Girald fitz Ansold gave to the monks of Tiron an oven and Dodo de Cruce sold an Oven next to the house, undated, fol. XIIv. Printed T1.147 (CXXVI).

Scribe A 
58/ Viscount Hugh of Le Puiset cedes to the monks of Tiron the right to two measures of wine, which he used to have in their vineyard at Gorzeias, 1129, fol. XIIIr. Printed T1.127 (CVIII).

Scribe A

59/ Notice that Harduin, Adelina and their son John have sold to the monks of Tiron for $£ 7$ 10s. three arpents of land at Grossela, undated, fol. XIIIr. Not printed by Merlet. See $\mathrm{n}^{\circ} 72$.

Scribe A

6o/ Notice that Provost John and Hubert Asinarius exchanged a chamber in Chartres with Lambert the smith, undated, fol. XIIIv. Printed T2.30 (CCLXI).

\section{Scribe A}

61/ Notice that Ansold Berbel had restored the land of Bretonneria and meadow, undated, fol. XIIIv. Printed T1.182 (CLIX).

Scribe A

62/ Notice that Hubert Asinarius prior of the Tironensian monks at Chartres and Gerbertus bought four agripennos of land at Gorzeis from Constantine of Saint-Martin for 230s., undated, fol. XIIIv. Printed T2.3 (CCXXIX).

Scribe A

63/ Notice that Renard of Artenario gave Nigelles to the monks of Tiron and the claims of Richard of Ogeriis were abandoned, undated, fol. XIIIIr. T2.5 (CCXXXI).

Scribe A

64/ Notice that Abbot William of Tiron conceded to Hugh of Vendôme and his wife the house of Orieldis for life, undated, fol. XIIIIr. Printed T2.29 (CCLVIII).

Scribe A

65/ Notice that Herbert de Ceresvilla and his wife gave themselves and their property to the Tironensian church, undated, fol. XIIIIr. Printed T2.45 (CCLXXIV).

Scribe A

66/ Notice that Hilduis wife of Glavin the butcher sold a house to the monks of Tiron, undated, fol. XIIIIr. Printed T1.73 (LII).

Scribe A

67/ Abbot William and the whole convent of Tiron sold to Hugh fitz Gerberga vines at Saint-Martin-du-Val and Hugh will render 3s. 3 d. in rent annually, undated, fol. XIIIIv. Printed T1.45 (XXIX).

\section{Scribe A}

68/ Notice that Ralph and Ansold Harpinus gave to the monks of Tiron vines, a house, land at Grosella and a house in St Peter Street with the promise of further legacies, undated, fol. XIIIIv. Printed T1.194 (CLXXIV).

Scribe A

http://www.unicaen.fr/mrsh/craham/revue/tabularia/print.php?dossier=dossier9\&file=07thompson.xml 
69/ Notice that Ralph the moneyer gave to monks of Tiron 10os. on (super) a house and land. This act also contains Orieldis' gift of a house in Chartres (see $n^{\circ} 64$ ), Hamelina's gift of her house and William the smith and his wife Osanna's grant of all their property and their house, undated, fol. XIIIIv. Printed T1.122 (CI).

Scribe A

70/ Notice that Hugh Morinus of the Porta Drocensis sold land to the monks of Tiron, which Hugh Asinarius bought on behalf of the monks, undated, fol. XVr. Printed T1.190 (CLXVII).

Scribe A

71/ Notice that Haudric and Hermentrut bought a garden from the canons of Saint-Martin and in her widowhood Hermentrut bought out her husband's part of the mortgage and gave it to the monks of Tiron. Two of them, Gosbert and Glavin, were given a life lease, undated, fol. XVr. Printed T2.6 (CCXXXII).

Scribe A

72/ Notice that Harduin, Adelina and their son John sold the monks of Tiron land at Grossella for $\mathfrak{E}_{7}$ 9S., undated, fol. XVr. Printed T2.7 (CCXXXIII). See $\mathrm{n}^{\circ} 59$.

Scribe A

73/ Notice that Pagan Dromadarius and his brother, Ansold, have given the house of their father, Warin, to the monks of Tiron by the hand of Bishop Geoffrey of Chartres, undated, fol. XVv. Printed T1.251 (CCXXII).

Scribe A

74/ Notice that Hugh of Pratella has rescinded to the monks of Tiron partly for the love of God and partly for money the 18s. rent that the monks paid him from Oisème in return for $£ 12$ dunois, done in Chartres in the monks' chapel by the hand of Bishop Geoffrey of Chartres, undated, fol. XVv. Printed T1.19o (CLXVIII). The style of this hand is similar to that of Scribe A, who may be writing differently to accommodate an additional act in the space available. To draw a distinction between these two styles this hand is referred to as "Unidentified hand 4".

Unidentified hand 4

75/ Philip [Augustus] king of the French issues letters of protection to the monks of Tiron, April 1194, fol. XVv. Printed T2.114 (CCCXXXIX).

An archaizing hand of probably late $15^{\text {th }}$ or early $16^{\text {th }}$-century

76/ Notice that Ansold fitz Godescalc gives himself and his property at Oisème to the monks of Tiron and not long after he lent Abbot William £2o to buy a carrucate of land; others donate the vicaria, undated, fol. XVIr. Printed T1.49 (CXXVII). A pancarte-type document.

Scribe A

77/ Notice that Guiburgis and her family conceded to the monks of Tiron the land at Villandon, given by William of Choes, undated, fol. XVIIr. Printed T1.135 (CXV).

Scribe A 
78/ Notice that Hugh of Villandon and his wife gave to the monks of Tiron land at Villandon, undated, fol. XVIIr. Printed T1.191 (CLXIX).

Scribe A

79/ Notice that Robert fitz Robert gave to the monks of Tiron land at Villandon, undated, fol. XVIIv. Printed T1.227 (CXCVII).

Scribe A

8o/ Notice that Ralph and Gilbert of Umbleriis sold to the monks of Tiron land at Villandon, held from the fee of Roger Chanard, undated, fol. XVIIv. Printed T1.152 (CXXVIII).

Scribe A

81/ Notice that Goscelin Gallus and his family withdraw their claim over land at Villandon given to the monks of Tiron, undated, fol. XVIIv. Printed T1.251 (CCXXIII).

Scribe A

82/ Notice that William of Villa, called Choes, and his wife, Agnes, gave to the monks of Tiron land at Villandon, partly for religious reasons and partly for $£ 10$ chartrain, undated, fol. XVIIIr. Printed T1.117 (XCVII).

Scribe A

83/ Notice that Robert fitz Robert gave land to the monks of Tiron at Villandon, undated, fol. XVIIIr. Printed T1.227 (CXCVIII).

Scribe A

84/ Notice that Ralph of Umbleriis and his brothers gave to the monks of Tiron the land that he used to hold at Villandon, undated, fol. XVIIIv. Printed T1.192 (CLXX). This act asserts that it is a chirograph in an introductory sentence.

Scribe A

85/ Notice that William fitz Ansold gave to the monks of Tiron three measures of oats and three half pennies rent on land they had been given by Guy of Umpharville, undated, fol. XVIIIv. Printed T2.10 (CCXXXVI).

Scribe A

86/ Notice that Guy of Ulmeto and his mother Maria gave to the monks of Tiron land at Villandon, which Odo Craton first disputed and then conceded in return for payment by Prior Robert of Villandon, undated but 1116-1137, fol. XIXr. Printed T1.153 (CXXVIII).

Scribe A

87/ Notice that Gilbert of Umbleriis and Theobald son of Girald of Gradu gave to the monks of Tiron land near the ditch of Mamemcurt in return for 2os., undated, fol. XIXr. Printed T1.228 (CC).

Scribe A

http://www.unicaen.fr/mrsh/craham/revue/tabularia/print.php?dossier=dossier9\&file=07thompson.xml 
88/ Notice that William Aculeus, son of Robert Aculeus, and his wife Elizabeth conceded to the monks of Tiron land given by William Choes and the land which he sold to the monks, for which they received 10os., undated, fol. XIXr. Printed T1.193 (CLXXI).

Scribe A

89/ Notice that Robert of Teuvilla and his two sons gave land to the monks of Tiron who were living at Villandon and received 68s., done in the archdeacon's house at Chartres, undated, fol. XIXv. Printed T2.45 (CCLXXV). The style of this hand is similar to that of Scribe A, who may be writing differently to accommodate additions in the space available. To draw a distinction between these two styles, this hand is referred to as "Unidentified hand 4 ".

Unidentified hand 4

90/ Notice that Hugh of Villecoc sold 2s. rent which he used to hold at Villandon and Villecoc for 25s., on the feast of St Mary in August, no year, fol. XIXv. Printed T2.46 (CCLXXVI). The style of this hand is similar to that of Scribe A, who may be writing differently to accommodate additions in the space available. To draw a distinction between these two styles this hand is referred to as "Unidentified hand 4".

Unidentified hand 4

91/ Geoffrey of Praele gave to the monks of Tiron the church of Saint Epagne of Ablis; Gerald Ensachalana gave to the monks two bovates at Murgersbetum; Count Guy of Rochefort gave to the monks 1os. annually from the paagium of Ablis to light the church; Gerald Ensaielana sold the monks land near the church; Aaletdis gave the monks land; Hugh the knight gave land; Hervey of Gallardon and Odo Herlandus conceded the tithe of three arpents; Bovardus of Bertocurt gave to the monks land where half a measure of wheat can be sown; Walter sine Nappis and Flandina his mother gave half the tithe of the land of Maenvilla, undated, fol. XXr. Printed T1.19 (VIII). A pancarte relating to Ablis.

Scribe A

92/ Reinbald of Coudray and his wife Agnes gave to the monks of Tiron living at Ablis land, undated, fol. XXr. Printed T2.10 (CCXXXVII).

Scribe A

93/ Notice that Gerald Ensaielana and his wife Amelina gave themselves to the church of Tiron in so far as they wanted to be monks and an arpent of land and a house on it, and received $£ 4$ 10s., undated, and that he gave another arpent and received 5os. and a measure of wheat. Another line is begun about Gerald's donations, but not completed, fol. XXv. Printed T1.57 (XXXVI).

Scribe A

94/ Count Guy of Rochefort, wishing to go to Jerusalem, commends himself to the prayers of Abbot Bernard and the convent, giving them a mill stone at Rochefort that rendered 20s. annually, before 1116, fol. XXv. Printed T1.17(VI).

Scribe A 
95/ Notice that Reginald fitz Harduin of Andovilla conceded the land at Prunay given by Ivo of Courville to the monks of Tiron, which he used to say belonged to his relatives, undated probably 1116-1137, fol. XXv. Printed T1.154 (CXXIX).

Scribe A

96/ Notice that Hugh of Lievreville, recognising the love which the monks of Tiron had shown to himself, his mother, brother and sister, promised that if he became a monk he would do so at Tiron and leave his property to the monks. He conceded his brother, Geoffrey Tyroht's gifts, placing a book on the altar as a sign of the gift, undated, fol. XXIr. Printed T1.229 (CCI).

Scribe A

97/ Notice that Marie of Lievreville, Hugh her son and Ansold her brother conceded to the monks of Tiron the land which Geoffrey Tyrot, her son, had given when he became a monk, and received 45s., done in the monks' chapel at Chartres, undated, fol. XXIr. Printed T1.157 (CXXXI).

Scribe A

98/ Ivo of Courville recounts how he gave to the monks of Tiron all the land he used to have at Augerville, except the carrucate that he had given to the monks of Chuisnes and another to the sick at Beaulieu, with the approval of Hugh son of Evrard of Le Puiset. He gave a mill and an oven at Courville and rights to fish once a year in his lake and sluices of Charruel. He gave 8s. rent at Forêtville, timber and pasturage in his woods and the right to take hay. He also gave land to the monks dwelling at Climart. Further gifts are noted, which were made in the market of Courville and confirmed by his successor, Fulk of Quercu, undated, fol. XXIv. Printed T1.32 (XVIII).

Scribe A

99/ Notice that, when Ivo of Courville renounced the world, he resigned to Count Theobald all that he held of him or the viscount. The count gave him 2oos. and promised he would protect all Ivo's benefactions and restore the lands to individuals nominated by Ivo if they could produce the same sum. Count Theobald's oaths were guaranteed by his mother, and his brother, Count Stephen, and the king of England gave his oath too, undated but before Countess Adela entered Marcigny, 1120, fol. XXIIr. Printed T1.104 (LXXXV).

Scribe A

100/ Notice that Stephen, chaplain of Le Puiset, and his brothers, Theobald, Ansold and Milo sold to the monks of Tiron all their land at Argentela, near the monks' house of Augerville, done in the bishop's hall at Chartres and conceded by their children at Augerville, undated, fol. XXIIv. Printed T1.158 (CXXXII).

Scribe A

101/ Notice that Viscount Geoffrey of Châteaudun gave to the monks of Tiron a tithe of the great tolls and a tithe of the paagium and foragium, and a tithe of the mint (mee monete proprie) and of salt in the presence of Bishop Geoffrey of Chartres and Abbot William, dated 1119, fol. XXIIIr. Printed T1.37 (XXI).

Unidentified hand 2 
102/ Notice that Reginald of Spiers and his wife gave to the monks of Tiron all their land at Monte Symphoriano and a mill on the River Aigre, meadows, vines and a garden, undated, fol. XXIIIr. Printed T1.118 (XCVIII).

Unidentified hand 2

103/ Notice that Viscount Geoffrey of Châteaudun and two monks of Riboeuf built a mill on the River Aigre, undated, fol. XXIIIr. Printed T1.160 (CXXXIV).

Unidentified hand 2

104/ Notice that Hugh of Lievreville, his mother, Marie and kinsman, Herbert Guitun, handed to the monks of Tiron all their land in vadimonium, receiving $£ 10$ chartrain in return, and they concede the lands to the monks, if they do not return from their pilgrimage to Jerusalem, but they may not recover the lands if they return inside five years, fol. XXIIIr. Printed T1.106 (LXXXVI).

Unidentified hand 3

105/ Notice that Hugh, the son of Viscount Geoffrey of Châteaudun confirmed to the monks of Tiron in year in which his father was held in Ursio's prison whatever "we" had in the fee of his father or of his mother, the venerable Heloyse, 6 January, fol. XXIVr. Printed T1.242 (CCXV).

Scribe A

106/ Notice that Ysanna wife of Engelrand of Nocé gave to the monks of Tiron vines at Châteaudun, undated, fol. XXIVr. Printed T2.12 (CCXXXIX).

Scribe A

107/ Notice that Garnier Oculus canis rescinds the 12d. rent which he had received from the monks for Ogier's vineyard, undated but witnessed by Abbot Archembaud of La Madeleine of Châteaudun, founded 1131, fol. XXIVr. Printed T1.177 (CLIV).

Scribe A

108/ Notice that Viscount Geoffrey of Châteaudun conceded to the monks of Tiron land in the Val St Anagnan, given by Algardis, wife of Ansold fitz Godescalc for the monks to build their houses, 1131, fol. XXIVv. Printed T1.175 (CLII).

Scribe A

109/ Notice that Blanche of Memberolles gave to the monks of Tiron vines at Connie, the tithe of Marboe, and her house in Châteaudun, undated, fol. XXIVv. Printed T1.136 (CXVI).

Scribe A

110/ Notice that Reginald of Espiers and his wife Ada give to the monks of Tiron half of the four arpents of vines, which they bought from their own rents and ready cash (pecunia mobili) at Châteaudun, probably before 1137, fol. XXIVv. Printed T1.181 (CLVIII).

Scribe A 
111/ A list of rents from the vines of Châteaudun, undated, fol. XXIVv. Printed T2.47 (CCLXXVII).

Scribe A

112/ The monks of Holy Trinity of Tiron and Peter of Péronville come to a settlement about the various disputes between them, since the time when Peter's father gave to the monks two carrucates of land to build their houses on the far side of the water of Péronville, dated 1135, fol. XXVr. Printed T1.220 (CXCIII).

Scribe A

113/ Notice that Solomon Dosnellus gave to the monks of Tiron half arpent at Montreuil, done at Orléans in 1132, fol. XXVIr. Printed T1.186 (CLXII).

Scribe A

114/ Notice that Peter of Péronville gave to the monks of Tiron the land of Vilerfresengis to complete the carrucate of land at Montreuil, restored the land of Pertis and conceded the tithe on land given them by Hildeardis des Près, undated, fol. XXVIv. Printed T1.230 (CCII).

Scribe A

115/ Notice that Peter of Péronville gave to the monks of Tiron 3 carrucates, one at Montreuil and the others at Villechoc, and he received $£ 10$ 10s. and a war horse, and he gave two arpents of land on the carrucate at Montreuil free from customs, so that they could build their houses. Two further incidents are narrated, undated, fol. XXVIv. Printed T1.177 (CLV).

Scribe A

116/ Notice that Haurricus gave to the monks of Tiron land at Péronville, partly for love and partly for earthly purposes, and the monk in charge of the obedientia of Péronville, Ernaudus Malboverius, gave him 20s., a white sheep and its lamb, undated, fol. XXVIIr. Printed T1.236 (CCVIII).

Scribe A

117/ Notice that Gosbert Pagan of Châteaudun and his brother, Guiard Trobel, gave all their land of Pertis to the monks of Tiron, retaining a portion that they may sell or mortgage, with arrangements for the provision of services specified. The abbot gave 40s. for this, undated, fol. XXVIIr. Printed T1.178 (CLVI).

Scribe A

118/ Notice that Peter of Péronville conceded the land of Ville Galli and water to the monks of Tiron, as well as a wood in the middle of the land and the land of Pertis, 1130, fol. XXVIIv. Printed T1.142 (CXXI).

Scribe A

119/ Notice that Hubert [son of Peter of Péronville] gives half an arpent of vines and half a house to the monks of Tiron, and the act ends with a note that the abbot made

http://www.unicaen.fr/mrsh/craham/revue/tabularia/print.php?dossier=dossier9\&file=07thompson.xml 
these agreements with Peter of Péronville, undated, fol. XXVIIIr. Printed T1.142 (CXXI).

Scribe A

120/ Notice that William of Plessis gave to the monks of Tiron, partly in alms and partly for money, all that he had at Cheldri and Orviler, undated, fol. XXVIIIr. Printed T2.11 (CCXXXVIII).

Scribe A

121/ Notice that Gerald Diabolus gave to the monks of Tiron his land of Choudre and Orviler on the terms that he would give them a measure of wheat and eighteen sestiers of oats for sowing on the land and a fourth part of the yield would be rendered to him and his heirs; and he added the whole tithe of Orviler, undated, fol. XXVIIIv. Printed T1.107 (LXXXVII).

Scribe A

122/ Notice that Helgod of Memberolles gave to the monks of Tiron a carrucate in Lesenvilla and Robert Bofigon gave all his land in the same place. The monks gave these lands to Pagan of Froovilla for three carrucates that he exchanged with them in Orviler and Choldre; and to ensure that the three carrucates remained with the monks, Blanche the mother of Helgod gave Pagan one carrucate from her dower at Lesenvilla and half an oven at Châteaudun, 1129, fol. XXIXr. Printed T1.129 (CIX).

Scribe A

123/ Notice that Pagan of Froovilla has undertaken to defend the exchange of lands at Orviler and Cheldrei and the monks gave Pagan's children a denarius to buy nuts in return for their approval, undated, fol. XXIXv. Printed T1.137 (CXVII).

Scribe A

124/ Notice that Countess Adela of Blois conceded all she had given Abbot Hugh and the monks of Tiron in the wood of Silvenon and at Ruissi, 1116-1120, fol. XXXr. Printed T1.28 (XIV).

Scribe A

125/ Notice that Count Theobold conceded all he had given to Abbot Hugh and the monks of Tiron in the wood of Silvenon and at Ruissi, after 1116, fol. XXXr. Not printed by Merlet.

Scribe A

126/ Notice that Count Theobold of Blois gave to the monks of Tiron 5s. rent from the gate of Blois, undated, fol. XXXr. Printed T1.40 (XXIII).

Scribe A

127/ Notice that Count Theobald of Blois gave annually a measure of the best wheat from his terragium of Marchenoir to Saint-Calais in exchange for the tithe which they used to have in the land of the monks of Saint Andrew of Sevelonia (Écomon), who 
undertook to give the canons of Saint-Calais one measure of oats, fol. XXXv. Printed T1.69 (XLIX).

Scribe A

128/ Notice that Ursio of Fréteval conceded to Abbot William and the monks of Tiron all that they had held in his fee from times past, 1141, fol. XXXv. Printed T2.35 (CCLXVII).

Scribe A

129/ Notice that Ursio of Fréteval conceded to the monks of Tiron land which John of Secora had given them at Verrerias, the tithe of Guicher, which John had given in the parish of Alteil, and the tithe of Bolvilla, which Hugh of Ialand gave, 1133, fol. XXXIr. Printed T1.206 (CLXXXIV).

Scribe A

130/ Notice that Bishop Geoffrey of Chartres excommunicated Viscount Geoffrey of Châteaudun and his sons, Hugh and Pagan, for the wrongs they had done to the monks of Tiron. Viscount Geoffrey died at Chartres, having been made a monk of Tiron, and his wife, Viscountess Helois and his son, Hugh, made peace with the monks, 1145, fol. XXXIv. Printed T2.38. The final lines of this act, after the dating clause, may have been added later; the scale of the handwriting is smaller and becomes increasingly more compressed.

Scribe A

131/ Notice that Viscount Geoffrey of Châteaudun gave to the monks of Tiron the land of Gorth and as much land around it as one land can plough, 1131, fol. XXXIIr. Printed T1.176 (CLIII). This hand shares some similarities with Scribe A, but there are differences.

Unidentified hand 5

132/ Notice that Bartholomew of Vendôme conceded to the monks of Tiron the land at Montem Luisel, which Reginald Roboratus had given them, and he conceded to them $8 \mathrm{~d}$. rent, which he used to receive from it. He also gives two carrucates of land next to Planum Baufredi and usages of woodlands and pasture, undated, fol. XXXIIr. Printed T2.1 (CCXXVII).

Scribe B

133/ Notice that Haimericus Baufredus and his brother, Hugh, who was a monk of Tiron, gave to the monks of Tiron the land of Castellis Baufredi, and the bugnonem de Acrania, undated, fol. XXXIIr. Printed T1.179 (CLVII).

Scribe B

134/ The same act is repeated with minor changes of spelling. Both are conceded by Viscount Geoffrey of Châteaudun, fol. XXXIIv. Not printed by Merlet.

Scribe B

http://www.unicaen.fr/mrsh/craham/revue/tabularia/print.php?dossier=dossier9\&file=07thompson.xml 
135/ Chirograph recording the agreement between the monks of Tiron and Viscount Geoffrey of Châteaudun and his wife, Heloisa. They gave four carrucates at FontaineRaoul, two carrucates at buinonium on the River Esgrenne, another two carrucates elsewhere on the river and all the land of Planis Baufredi and one carrucate next to the castle of Mondoubleau, called Fossa Roberti. They conceded pasture for the animals living at these places, except for hay, pasture for pigs and timber for building and firewood. They gave half the tithe of their return of coins at Châteaudun, which they had formerly given in full to the monks of Tiron, on condition that it should be given forever to the convent there, 1133, fol. XXXIIv. Printed T1.207 (CLXXXV).

Scribe B

136/ Notice that Robert of Bullo at the point of death asked the monks of Tiron living at Footellis to make him a monk and gave them what he had in the mill of Bullo, undated, fol. XXXIIIr. Printed T2.85 (CCCXII).

\section{Unidentified hand 6}

137/ Agnes of Montigny, before she married Odo, gave to the monks of Tiron enough to establish a settlement on the River Yron, and her husband subsequently increased these gifts, undated, fol. XXXIIIv. Printed T1.22 (X).

Scribe B

138/ Notice that Warin gave to the monks of Tiron seven ploughlands at Fouteaux and a place to build their dwellings, undated, fol. XXXIIIIr. Printed T1.87 (LXIX).

Scribe B

139/ Bishop Geoffrey of Chartres notifies an agreement between the monks of Tiron and the canons of La Madeleine of Châteaudun concerning the church of Ruan, 1133, fol. XXXIIIIr. Printed T1.208 (CLXXXVI). The cartulary text is undated but the date is provided by Merlet who consulted a now lost original in the Bibliothèque municipale of Vendôme. This act is followed by one line of another notice.

Scribe B

140/ Bishop Geoffrey of Chartres notifies the settlement of a dispute between Abbot William and the monks of Tiron and Abbot Hugh and the monks of Saint-Père of Chartres concerning the land of Bois Ruffin and the land at Mereleht, undated, fol. XXXVv. Printed T1.155 (CXXX).

Scribe B

141/ Notice that Robert, brother of Geoffrey of Ouzouer, on the point of departure for Jerusalem, gave to the monks of Tiron one carrucate at sanctas valles, which his brother subsequently disputed. The dispute was settled by the payment of 6os. and twelve measures of wheat by the monks, undated, fol. XXXVv. Printed T2.57 (CCLXXXIX). This act does not appear in the contents pages and has no roman number. It is likely to have been one of the last acts entered in the cartulary in the mid twelfth century before work on the cartulary project was abandoned. It is written by a hand which resembles that of Scribe A, but there are also some differences.

Unidentified hand 7 
142/ Abbot Bernier of Bonneval notifies that Abbot William and the monks of Tiron asked for the chapel of Saint-Mesme on the River Osanne, indicating that nothing belonging to the mother church at Trizay-lès-Bonneval would be withheld, undated, fol. XXXVIr. Printed T2.16 (CCXLIII).

Scribe B

143/ Notice that Pagan of Bosco gave to the monks of Tiron land at Saint-Mesme while he lived, which his widow Matilda gave after his death, with the approval of her new husband and her daughters and their husbands, undated, fol. XXXVIv. Printed T2.72 (CCXCVIII).

Scribe B

144/ Notice that Reginald Enforcet gave to the monks of Tiron half the land he used to hold from the fee of Bartholomew of Vendome at Montem Luserni, given with the approval of Viscount Geoffrey of Châteaudun and his wife Hellui in whose fee it lay, undated, fol. XXXVIv. Printed T1.103 (LXXXIV).

Scribe B

145/ Hugh of Poncaio notifies that he gives to the monks of Tiron at Montem Lusernum two land holdings free from all secular exactions; Hugh of Valenis gives what he used to have in these two holdings and Henry of Caresmo conceded half the tithe of the place. Hugh of Valenis received from Hugh of Poncaio the fee of Hamericus Baufredi in exchange for all this and recently Hugh of Poncaio conceded his bees and wax found in the wood, together with two further carrucates in another place, undated, fol. XXXVIIr. Printed T1.97 (LXXVIII).

Scribe B

146/ Notice that Goscelin Borrel gave to the monks of Tiron by the hand of Bishop Geoffrey the church of St George on the day of its dedication and confirmed it later in the presence of Count Theobald and Viscount Geoffrey, undated, fol. XXXVIv. Printed T2.7 (CCXXXIV). This act has no roman number and does not appear in the $12^{\text {th }}$-century contents list.

Unidentified hand 8

147/ Notice that Pagan Lupus gave to the monks of Tiron meadow and land at Hatinval and after some years when he wished to go to Jerusalem he gave them all his land there and received 35s. Notice that Andrew Cholet and Moreherius of Nogent gave the church of Saint Rémy of Néron, and later, when wounded, he conceded his part of the oven of Néron and the other part was conceded by Moreherius. Germundus Niger gave an arpent next to the church and another next to the river. Osbern the maior of Néron gave an arpent of land, Guiard Tort another, Godescalc de Bosseria gave to the monks his part of the tithe of their land and of the animals and Simon of Monte Pinzon challenged this, but later conceded it before the bishop. William of Maintenon gave two ploughlands. Moreherius gave two arpents of meadow and Walter de Corbones had 12d. there, undated, fol. XXXVIIv. Printed T1.101 (LXXXII). A pancarte document.

Scribe B 
148/ Notice that Stephen Paganus, his daughter and her intended husband gave half their inheritance to the monks of Tiron, retaining the rest to do with as they wished and promising that they would bring no future claim, undated, fol. XXXVIIIv. Printed T1.161 (CXXXV). A line has been omitted and inserted at the end of the act.

Scribe B

149/ Notice that the monks bought meadow from Robert Gai for which they paid $2 \mathrm{~d}$. annually on Ascension day, done in the time of Prior Achard, and that Geubertus Ledreies conceded all the alms they had on his land, undated, done in the time of Walter Brutellus, fol. XXXVIIIv. Printed T2.13 (CCXL).

Scribe B

150/ Notice that when Constantius took the habit in the monastery of Tiron he gave the Tironensian monks dwelling at Saint Rémy vines from which Peter of Theonisvilla was accustomed to receive $6 \mathrm{~d}$. rent, and Peter gave that to the monks. Some years later the monks sold the vines to Durand, a townsman of Nogent, in return for an annual rent of $8 \mathrm{~d}$. and Peter conceded that too, undated, fol. XXXIXr. Printed T2.75 (CCCI).

Scribe B

151/ Notice that Odo of Orme and Aldeburg his wife conceded to the monks of Tiron the land on the River Loir which was from their fee, undated, fol. XXXIXr. Printed T1.58 (XXXVII). An abbreviated version of this act appears in $n^{\circ} 154$. This may be Scribe A, writing to a smaller scale and introducing features of style found in the handwriting of diplomas.

Unidentified hand 2

152/ Notice that the monks of Cluny and the monks of Saint-Denis of Nogent-le-Rotrou conceded to the monks of Tiron whatever land they used to hold beyond the River Loir and up to the paved road to Chartres, where the monks of Tiron have their dwelling. For this concession, Bishop Geoffrey of Chartres and his brother, Goscelin of Lèves, conceded to the monks of Cluny whatever Pagan of Orme holds of their fee and Hugh of Rivray from him, undated, fol. XXXIXv. Printed T1.58 (XXXVIII). Notice describes how this chirograph was read in the chapter at Nogent-le-Rotrou.

Scribe B

153/ After a preamble, Bishop Geoffrey of Chartres and his brother Goscelinus give to the monks of Tiron four carrucates next to the Loir water, an oven in Lèves, where there shall be no other oven and all men must use it. More recently they give a measure of wheat in the mill of Longo Saltu; Hugh of Rivray gave all his land between the road to Chartres and the Loir water, and the tithe of this land and four carrucates of their own demesne land were given by the canons of Saint Nicholas of Courville, undated, fol. XXXIXv. Printed T1.70 (L), but the text is supplemented with material from the next act $\mathrm{n}^{\circ} 154$, which does not have the preamble.

Scribe B

154/ Bishop Geoffrey of Chartres and his brother Goscelinus give to the monks of Tiron four carrucates of land next to the Loir water, an oven in Lèves where there shall be no 
other oven and all men must use it. More recently they give a measure of wheat in the mill of Longo Saltu; Hugh of Rivray gave all his land between the road to Chartres and the Loir water, and the tithe of this land and the measure of wheat Hugh of Rivray gave all his land between the road to Chartres and the Loir water, the tithe of this land and four carrucates of their own demesne land were given by the canons of Saint Nicholas of Courville. Odo of Orme and Aldeburg his wife conceded to the monks of Tiron the land on the River Loir which was from their fee. William Aculeus gave the vicariam, half of which was conceded by the holder, Herbert fitz Edward, and the baneriam was given by various families whose names are appended, undated, fol. XLr. Not printed by Merlet, but used by him to supplement act $n^{\circ} 153$. Single sheet original survives as ADEL H 1514, which has the preamble and all the text in $n^{\circ} 154$. Names of some witnesses have been erased from the central section of this act.

Scribe B

155/ Notice that Robert fitz Hervey gave and conceded to the monks of Tiron serving God at Châtaigniers his land at Coldreio, which was later disputed by Hugh of Vovis in the court of William Gouet, and Hugh conceded it to the monks, undated, fol. XLv. Printed T1.77 (LVII).

Scribe B

156/ Notice that William Gouet, his wife, Eustachia, and sons make a concession to Abbot Bernard and the monks of Tiron. The concession is itemised, along with tithes and the church of St Thomas of Soizé, which were surrendered into the hand of Bishop Geoffrey of Chartres. Other gifts are listed and the consecration of the cemetery by Bishop Geoffrey is reported. William Gouet's deathbed gifts are described and the concession of his son. The benefaction of Robert fitz Hervey ( $\left.n^{\circ} 155\right)$ is narrated without reference to the later dispute and two further donations are listed, undated, fol. XLIr. Printed T1.24 (XII) up to Robert fitz Hervey's donation. Robert's donation is printed as T1.77 (LVII) and the other donations as T1.196 (CLXXV) and T1.162 (CXXXVI). A pancarte document, sealed by Bishop Geoffrey, who concedes all that is in it.

Scribe B

157/ Notice that Peter Rex gave to the monks of Tiron at Châtaigners a carrucate of land, done before Ralph of Beaugency and written by Geoffrey Grossinus, the chancellor, 1126, fol. XLIIv. Printed T1.99 (LXXIX). This act has been written after the main sequence, as it has been added to the contents page, where it was given a roman number (clii), which duplicates the one below it in the contents list, but that number has not been added to the text. The scribe who was numbering the acts must have intended to amend the numbering, but stopped his work before he could do so. The hand is similar to that of Scribe A.

Unidentified hand 9

158/ Notice that Hubert Tortus of Montdoubleau give to the monks of Tiron a mill, land and meadow at Masenge, done in the chapter of Tiron, 1131, fol. XLIIv. Printed T1.174 (CLI).

Scribe B

http://www.unicaen.fr/mrsh/craham/revue/tabularia/print.php?dossier=dossier9\&file=07thompson.xml 
159/ Notice that a knight gave a mill near Masengiacum, rendering 2d. annually, when he became a monk, and the monks held this for many years until Bernard capicerius of the cathedral of Chartres asked the monks to give half the mill and meadows to the church of Chartres for an annual sum of 12d., done in the chapter of Chartres in the time of Dean Zacharias, undated, fol. XLIIIr. Printed T2.9 (CCXXXV).

Scribe B

160/ Notice that Geoffrey Burrello gave to the monks of Tiron all his land between Sissé and the forest, given to him by Count Theobald, and the tithe of this land had been held by the canons of Saint-Calais. At the intervention of Count Theobald, an exchange was made with property held by the monks elsewhere, undated, fol. XLIIIv. Printed T1.68 (XLVIII).

Scribe B

161/ Geoffrey Burrello concedes to the monks of Tiron the land that Count Stephen had given his father, a mill, half a fishery, and meadow, done in the time of King Louis and Bishop Geoffrey of Chartres (1116-1149), fol. XLIIIv. Printed T1.67 (XLVII). Appears to be the first person act which is related as a notice at $n^{\circ} 160$.

Scribe B

162/ Bishop Froger of Sées (1159-82) notifies that Pagan of Courgeoût has given to the monastery of Tiron and the monks dwelling there the church of Saint-Lomer of Courgeoût and concedes what William of Blavou had given in church of Saint-Jouin, undated, fol. XLIIIv. Printed T2.86 (CCCXIII).

Unidentified hand 7

163/ Notice that when Robert des Roches gave his daughter, Sibyl, in marriage to Reginald of Châteaurenault, he also gave the land of Saint-Georges of Peglait and the land there, which hermits were accustomed to cultivate around the church, together with half a wood. Reginald and his wife Sibyl, gave the church and land to the Holy Saviour of Tiron and the brothers in religious habits who were dwelling there. Robert of Roches conceded this gift. Later the monks told Robert and Reginald that they could not live there and Robert and Reginald came to the site and made a new endowment, and this was given to the monks of Tiron and conceded by Reginald's sons, Reginald and Guicher, undated, fol. XLIIIIr. Printed T2.88 (CCCXV).

Scribe B

164/ Notice that Robert des Roches gave his daughter, Sibyl, in marriage to Reginald of Châteaurenault with the land of Saint-Georges de Peglait and half the wood that he had there. Later Reginald and his wife gave it to the monks of Tiron, but they found that they could not live there and asked Robert and Reginald for land where they could live, and it was given, undated, fol. XLIIIIv. This version is not printed by Merlet.

Scribe B

165/ Notice that Arsendis of Perei and her daughter gave to the monks of Tiron a mill near the monks' house at Monrion on the understanding that Villana Rabella and Warin Grao, to whom half the site belonged, would build a mill and half of it would belong to 
the monks, along with the fishing. Villana and Warin would repair the mill and send their men there for milling, undated, fol. XLVv. Printed T1.231 (CCIII).

Scribe B

166/ Notice that Hugh Bormaudus and his wife Ascelina gave to the monks of Monrion a certain mill site called the new mill for which they received 2os. and the monks subsequently made a mill. Hugh, Ascelina and her mother made this gift by placing a knife on the altar of the church of Monrion, and Henry the lord of the fee conceded it for love of God and Count Theobald, fol. XLVv. Printed T2.74 (CCC).

Scribe B

167/ Notice that Hugh Bormaudus and his wife Ascelina gave to the monks of Monrion a certain mill site called the new mill for which they received 2os. Henry the lord of the fee conceded it for love of God and Count Theobald. This is repeated with tiny changes and the same witness list, fol. XLVIr. Not printed by Merlet.

Scribe B

168/ Notice that Arsendis of Perei and her daughter gave to the monks of Tiron a mill near the monks' house at Monrion on the understanding that Villana Rabella and Warin Grao to whom half the site belonged would build a mill and half of it would belong to the monks along with the fishing. Villana and Warin would repair the mill and send their men there for milling, undated, fol. XLVIr. Not printed by Merlet.

Scribe B

169/ Notice that Countess Adela, mother of Count Theobald gave to the monks of Tiron all her lordship (dominium) at Monrion and asked Odo Mala Musca and his sister Regina to cede their land to it, undated but before 1120, fol. XLVIv. Printed T1.40 (XXIV).

Scribe B

170/ Notice that in his last illness Ursio of Fréteval repented of the ills he had done to the monks of Tiron and restored the possessions that he had seized, which are itemised, undated but before 1149, fol. XLVIv. Printed T2.59 (CCXC).

Scribe B

171/ Notice that William of Vaupillon and his wife Agnes gave to the monks of Tiron two carrucates in the Vallis Joscelini and various other properties including pasture, a lake, a mill, an oven, rights to firewood to fuel the oven and various tithes. When they came to Tiron at their conversion William and Agnes conceded Agnes' dower to their successor Ralph of Guitot, so the monks of Tiron could hold all this in peace, and Ralph retained a part of this chirograph, undated, fol. XLVIIr. Printed T1.224 (CXCV).

Perhaps unidentified hand 6

172/ Writ of King Richard [I] of England, duke of Normandy and Aquitaine, count of Anjou notifying that he has confirmed to the abbot and monks of Tiron the alms of 20 marks to be paid on the feast of St Michael from his exchequer at London, dated 
10 September 1189 (wrongly dated by Merlet to 1188), fol. XLVIIv. Printed T2.108 (CCCXXXI).

Late $13^{\text {th }}$ - or earlier $14^{\text {th }}$-century hand

173/ Writ of King Henry [I] of England (1100-1135) that he has conceded the land at Barton and Kington in Herefordshire, given by Adam de Port to the monks of Tiron, undated but probably 1121, fol. XLVIIIr. Printed T1.29 (XV).

Scribe B

174/ Writ of King Henry [I] of England to the abbey and whole convent of Tiron conceding to the abbey of Cemais the lands and everything that Robert fitz Martin had given or would give to the abbey. The abbey would be as free as it had been when it was a cell of Tiron, undated but probably 1120, fol. XLVIIIr. Printed T1.41 (XXV).

Scribe B

175/ Writ of King Henry [I] of England that the property of the monks of Tiron shall be free from tolls and customs throughout his lands, undated but probably before 1116, fol. XLVIIIr. Printed T1.75 (LIV).

Scribe B

176/ Writ of King Henry [I] of England and duke of Normandy to Archbishop Geoffrey of Rouen, Count Henry of Eu and Adam of Grémonville that he has conceded to the monks of Tiron the wood, church, land and tithes, given by Adam, undated but probably 25 December 1115, fol. XLVIIIr. Printed T1. 27 (XIII).

Scribe B

177/ Writ of King Henry [I] of England that he concedes to the monks of Tiron Robert fitz Martin's gifts in Wales, undated but probably 1118, fol. XLVIIIr. Single sheet original WCM 4268a. Printed as T1.42 (XXVI).

Scribe B

178/ Writ of Earl Robert of Leicester notifying that he has exempted the abbot and monks of Tiron from all customs on their property in his land in Normandy, undated, fol. XLVIIIv. Printed T1.162 (CXXXVII).

Scribe B

179/ Notice that Ascelina wife of Guimund gave to the monks of Tiron, dwelling at St Andrew [of Hamble-le-Rice, Hants] the house that her brother Roaudus gave her and all the land she used to hold of the monks, and she conceded what her brother had given when he became a monk, undated, fol. XLVIIIv. Printed T2.31 (CCLXII).

Scribe A

180/ Writ of Earl Henry of Northumberland, son of the king of Scots, notifying that he had conceded and confirmed his father's gift to the monks of Tiron of one ship a year free of can. The ships and men are to have his peace and he extends his father's 
gift throughout his land of Northumbria, undated but after 1140, fol. XLVIIIv. Single sheet original ADEL H 1419. Printed T2.14 (CCXLI).

181/ Writ of the empress Matilda, daughter of King Henry and lady of the English notifying that she has rendered and conceded to the monks of Tiron 15 marks of silver, which her father had given them from the treasury at Winchester, and she increased it by five marks annually to be paid from the farm of Winchester, undated at Oxford probably in 1141, fol. XLIXr. Printed T1.109 (LXXXVIII).

Scribe B

182/ Writ of David king of the Scots notifying that he has given and conceded to the church of Holy Trinity of Tiron an exemption from can for one ship annually in Scottish waters and the ship and the men are to have his peace, undated but before 1140 (see $\mathrm{n}^{\circ}$ 180), fol. XLIXr. Printed T1.80 (LX).

Scribe B

183/ Writ of Henry [II] king of the English, duke of the Normans and Aquitanians, count of the Angevins that he has given to the monks of Tiron five marks of silver on top of the fifteen marks of silver that his grandfather, King Henry, had given to them, undated but before 1165, fol. XLIXr. Single sheet original WCM 18928. Printed T2.82 (CCCIX).

Unidentified hand 10

184/ Writ of Count Waleran of Meulan to his bailiffs and servants at Pont-Audemer exempting the property of the monks of Tiron from all tolls and customs in his lands, undated, fol. XLIXr. Printed T1.76 (LV).

Scribe B

185/ Writ of Count Waleran of Meulan to his bailiffs and servants at Pont Audemer notifying that he had given the abbot of Tiron two thousand herrings every year, which are to be delivered at Pont-Audemer, undated, fol. XLIXv. Printed T1.77 (LVI).

Scribe B

186/ Emma wife of Roger Alis notifies that she has given to the monks of Tiron dwelling at St Andrew of Hamble the land and meadow that she holds at Auditona at the request of Ruallon who was being made a monk, fol. XLIXv. undated. Printed T1.232 (CCIV).

Unidentified scribe 11 who is perhaps Scribe A

187/ Notice that Peter fitz Anger, Agnes his wife and their children conceded to the church of Tiron and the monks a thousand herrings annually which are to be taken from a stall that Peter held in the market, undated, fol. XLIXv. Printed T2.84 (CCCXI).

Scribe B

188/ Writ of Henry, duke of the Normans and Aquitanians and count of the Angevins notifying that he conceded and confirmed to the monks of Tiron twenty marks of silver

http://www.unicaen.fr/mrsh/craham/revue/tabularia/print.php?dossier=dossier9\&file=07thompson.xml 
annually from the treasury at Winchester, that is fifteen marks given by his grandfather, King Henry, and five marks, given by his mother, the empress as her charter testifies, 1152-1154, fol. XLIXv. Single sheet original WCM 10627. Printed T2.37 (CCLXVIII).

Unidentified hand 2 who may be Scribe A

189/ Writ of King Henry I of England, duke of the Normans notifying that he has given to the monks of Tiron fifteen marks of silver for their footwear to be paid at the treasury at Winchester each year, undated, fol. Lr. Printed T1.43 (XXVII).

Unidentified hand 2 who may be Scribe A

190/ Notice that William of Fontenillo gave to the monks of Tiron 2s. in rent, which William Aviron paid him annually, undated, fol. Lr. Single sheet original survives as ADEL H 1737. Printed T1.163 (CXXXVIII).

Scribe B

191/ Writ of Henry [II] king of the English, duke of the Normans and Aquitanians, count of the Angevins that he has conceded and confirmed to the monks of Tiron fifteen marks of silver annually for the footwear to be received from the treasury at the exchequer as his grandfather, King Henry, had given it and confirmed with his charter, done at Le Mans, undated, but before 1158, fol. Lr. Single sheet original WCM 10625. Printed as T2.81 (CCCVIII).

Unidentified hand 12

192/ R. fitz Durand notifies that he has given to the church of the Holy Saviour of Tiron seven measures of salt annually, undated, fol. Lv. Printed T1.88 (LXX).

Scribe B

193/ Notice that Roger de Port gave to the monks of Andwell the mill which stood at their gate and the land associated with it, undated, fol. Lv. Single sheet original survives as WCM 2793. The same symbol of a cross with dots in each of the areas between the arms of the cross appears on the single sheet document and in the cartulary. Printed T1.60 (XXXIX).

Scribe B

194/ Count Fulk of the Angevins gives instructions that the monks of Tiron are to be free of customs and dues throughout his lands, undated, before 1129, fol. LIr. Printed T1.63 (XLIV).

Scribe B

195/ Count Geoffrey of the Angevins gives instructions that the monks of Tiron are to be free of customs and dues throughout his lands, undated, fol. LIr. Not printed by Merlet, but referred to in footnote T1.63.

Scribe B

196/ Robert of Clarofonte notifies that, with the approval of his wife Ascelina, he gives and concedes to the monks of Tiron 1os. a year from the rents of Monte Guimeri to buy 
oil for the lamp that burns before the most blessed Abbot Bernard's tomb, undated, fol. LIr. Printed T2.15 (CCXLII). This act does not appear in the contents list and has no roman number.

Unidentified hand 3

197/ Notice that William of Auteuil and his wife Amelina give to the monks of Tiron five arpents of land near Mortagne and the tithes of Verrierias and Peix for the son to become a monk (monachando), done at the monks' house at Mortagne, undated, fol. LIr. Printed T2.91 (CCCXVIII). This act does not appear in the contents list and has no roman number.

Unidentified hand 3

198/ Notice that Pagan fitz Berlay and Robert his brother gave to the monks of Tiron two arpents of meadow on the River Erre and their wives conceded it later; Robert Raerius gave another, undated, fol. LIv. Printed T1.172 (CXLIX).

Scribe B

199/ Notice that Pagan of Courgeoût and wife gave one arpent next to the arpents of meadow and placed his gift on the altar of the crucified one together with a knife, undated, fol. LIv. This act is printed at the end of T1.172 (CXLIX), a pancarte document.

Scribe B

200/ Notice that Cecilia of Longpont gave an arpent of meadow in Longo Prato, undated, fol. LIv. Printed T2.77 (CCCIII).

Scribe B

201/ Notice that Robert de Campellis gave to the monks of Tiron an arpent of meadow next to that described in act $n^{\circ} 200$, undated, fol. LIIr. This act is printed at the end of T2.77 (CCCIII). Act $\mathrm{n}^{\text {os }}$ 198-201 may all have been copied from one pancarte-type document.

Scribe B

202/ Walter Hai, viscount of Mollan, gives to the monks of Tiron his weir of Messe and he had given an arpent of vines which his wife, Viscountess Ermeniardis, had bought, 1135, fol. LIIr. Printed T1.218 (CXCI).

Scribe B

203/ Notice that Oliver of Saint-Julian gave to the monks of Tiron two arpents of meadow, which in the meadows of the park, which was conceded by William of Maisnilio and Drogo of Courslain, undated, fol. LIIv. Printed T1.48 (CCLXXVIII).

Scribe B

204/ Notice that William of Glanville gave to the church of Saint Saviour of Tiron eight measures of salt from his tithe; recently he gave a man called Leotoldus and his holding with his service. Others gave small amounts of salt, undated, fol. LIIIr. Printed T1.164 (CXXXIX).

Scribe B 
205/ William of Glos, Goscelin the chaplain, the clerks and burgesses of L'Aigle write to Abbot William of Tiron, indicating that the confraternity has provided 43s. for the monks and has purchased herrings, undated, fol. LIIIv. Printed T1.91 (LXXII).

Scribe B

206/ Notice that Alexander of Noerio has given the monks of Tiron whatever he had at Mesnilium Berterii and the meadows he had there, undated, fol. LIIIIr. Printed T2.16 (CCXLIV).

Scribe B

207/ Notice that Robert the possessor of Crasville gave to the monks of Tiron the church of Crasville with its associated property, the tithes of his mills, a carrucate in Crasville and another in Rochefort, and his demesne pasture for their animals, undated, fol. LIIIIv. Printed T1.102 (LXXXIII).

Scribe B

208/ Archbishop Hugh of Rouen notifies that he has conceded to the monks of Tiron dwelling at Crasville the church of Crasville, tithes and other alms, including the gifts of Waleran of Rochefort, undated but between 1129-1164, fol. LIIIIv. Printed T1.103 (CLXXII). This act does not appear in the contents list and has no roman number.

Unidentified hand 13

209/ Notice that Gilbert gave to the monks of Tiron dwelling at Saint-Sylvestre [of Clères] land at Basse, woodlands, timber, a tithe of his food, meat and cheese, a fishpond near Clères, a garden with adjoining meadow, his share of the proceeds of his mills, pasture for their pigs and other animals, undated, fol. LIIIIv. Printed T2.17 (CCXLV).

Scribe B

210/ John the dean of Le Mans abandons all rights over priory of Montaillé, 1280, fol. LVr. Printed T2.193 (CCCXCIX). A single archaizing hand has added three acts on this house, see $\mathrm{n}^{\text {os }} 224$ and 318 .

$$
\text { Late } 15^{\text {th }} \text { - or early } 16^{\text {th }} \text {-century hand }
$$

211/ Notice that Walter de l'Isle gives and concedes to the monks of Tiron, who live at Saint-Sylvestre of Clères, his land of Bessam and received from Ralph Canteslo, then the prior, 30 s. in the coin of Rouen and the fleece in which he was clad, undated, fol. LVr. Printed T2.77 (CCCIV).

Scribe B

212/ Notice that William of Courcerault gave the Holy Saviour of Tiron whatever he possessed in the fee of Saint-Germain in demesne: land, wood and mills, and he conceded recently that which anyone might give in his fee, for which the monks gave him 20os. and his children 17s., undated, fol. LVv. Printed T2.50 (CCLXXXI).

Scribe B

213/ Notice that Matthew of Vernon gave to the monks of Holy Trinity of Tiron land at Tourny opposite the place where they had built their dwellings and a small wood near 
their house, and a mill and woodland at Pressagny l'Orgueilleux. This was done by the hand of Archbishop Hugh of Rouen (1129-1164) at Rouen, and William the priest of Tourny gave and conceded tithes. Later still in the time of Ralph the beltmaker, who was the prior, Robert Rex of Pressagny gave a toll of nuts for which Ralph gave him 11s., undated, fol. LVIr. Printed T1.211 (CLXXXVII).

Scribe B

214/ Notice that Gilbert Treholt gave three acras of land; Walter Granearius at his conversion gave seven acres of land, which had been disputed and three acres elsewhere and a tithe of his copse; Ralph fitz Adeles and Oelardus his brother gave an acre of land; Eustachia, sister of Matthew, gave six acres of land and in the parish of Fontineii; Maurice the clerk and his mother, Ascelina, gave a land near their house, where the monks had planted a vineyard and copse, undated, fol. LVIv. Printed T1.213 (CLXXXVII); although given the arabic number 214, this text is in fact a continuation of the previous act, which is a pancarte for the community at Tourny.

Scribe B

215/ Notice that Matthew of Vernon gives to the monks of Tiron all his land in the area where the monks had settled, the wood of Tronchet and whatever his men might give. He did this before he was married, and his wife, Isabel, conceded it later. Matthew's sister, Eustachia, later conceded six acres from Matthew's fees and other small gifts are itemised, undated, fol. LVIIr. Printed T1.241 (CCXIV).

Scribe B

216/ Notice that William the mason of Mortagne and Hersendis his wife gave to the monks of Tiron at the point of their conversion, for they were monks of Tiron, half a house, with the other half being left to his grandson, Rainier, who was to hold his own half of the monks and have custody of the monks' half during his lifetime and that of his heirs, undated, fol. LVIIv. Printed T1.165 (CXL).

Scribe B

217/ Notice that Seibrand of La Forêt conceded to the monks of Tiron the rights of high justice (sanguinem terre eorum) over their land of Tilliolo and the monks gave four sestiers of oats in return, undated, fol. LVIIv. Printed T1.62 (XLII).

Unidentified hand 14

218/ Notice that William of Dillon gave to the monks of Tiron the pastum which he had annually at Sischateria on the feast of the assumption of the Virgin Mary and the monks gave 5s. for this gift, undated, fol. LVIIv. Printed T1.63 (XLIII).

Unidentified hand 14

219/ Notice that Gerard de Giba gave to the monks of Tiron one oscham of land at Malum Foramen with adjoining woodland and the monks gave countergifts, including a cow with two calves, fol. LVIIv. Printed T1.123 (CIII).

Unidentified hand 14 
220/ Notice that Hameric Mala Pugna gave land in the fields of Cublerarie to the monks of Tiron and the monks gave 9s. and a measure of wheat in return, and they released him from the debt of a certain ox which he had bought from them, fol. LVIIv. Printed T1.124 (CIV).

Unidentified hand 14

221/ Notice that Seibrand of la Forêt gave to the monks of Tiron land at Bellum Visum and brother Gerald the Norman, prior of Le Theil, gave him a horse, undated, fol. LVIIIr. Printed T1.123 (CII).

Unidentified hand 14

222/ Notice that Gerald Jarrocellus gave to the monks of Tiron land in the honour of Saint-Maximin, cultivated by Geoffrey Flamatus, undated, fol. LVIIIr. Printed T1.124 $(\mathrm{CV})$.

Unidentified hand 14

223/ Pope Alexander III confirms the possessions of the monastery of Tiron, undated, fol. LVIIIr. Printed T2.98 (CCCXXVI). This act is dated by Merlet to 1175-6.

Unidentified hand 15

224/ Hamelin lord of Milicie notifies that he gives, concedes and confirms all the possessions of the house of Montaillé and the monks of Holy Trinity Tiron serving God there, 1225, fol. LIXv. Printed T2.136 (CCCLIX). A single archaizing hand has added three acts on this house, see $\mathrm{n}^{\mathrm{os}} 210$ and 318 .

Late $15^{\text {th }}$ - or early $16^{\text {th }}$-century hand

225/ Notice that Hugh of Mont Bernard, Roschus of Beaugency, Lebertus of Paveia and Theodoric Pluisnela, their wives and the sons of Theodoric withdrew their claims to the tithe of animals which they had disputed with the monks of Tiron dwelling at Saintry. Recently they gave the tithe of four agripenni of land of the monks' choice, undated, fol. LXv. Printed T1.232 (CCV).

Perhaps Scribe A

226/ Notice that Hugh of Caorchis and Richel of Carenconvilla, their sons, and Roscha of Beaugency conceded to the monks of Tiron tithes which they used to take from their dwellings at Saintry and Odo of Caorchis conceded in the presence of Bishop John of Orléans and Ralph of Beaugency in the castle at Beaugency, but later denied it and harrassed the monks. Finally he conceded it with his brothers Hugh and Geoffrey, undated but before Bishop John's death in 1135, fol. LXv. Printed T1.61 (XLI).

Perhaps Scribe A

227/ King Louis [VI] of France notifies that he has given four carrucates of land at Saintry to the monks of Tiron and conceded it to them forever; besides he concedes the wood of Melleray to settle and for their for their housing and fuel, 1115, fol. LXIr. Printed T1.18 (VII).

Scribe B 
228/ Bishop John of Orléans notifies that Umbald Rufus and Hugh Chaorcensis and others have resigned the tithe of animals at Saintry into his hand for the use of the monks of Tiron and the bishop has made this known in his letters, undated but before 1135, fol. LXIr. Printed T1.100 (LXXX).

Scribe B

229/ King Louis [VI] France notifies that he concedes to the church of Tiron his man, Archenbaud, from all customs and exactions which he used to obtain from him, 1129, fol. LXIr. Printed T1.127 (CVII).

Scribe B

230/ King Louis [VII] of France and duke of the Aquitanians notifies that he concedes the land given to the monks of Tiron by Antelmus de Groolento, 1138, fol. LXIv. Printed T1.247 (CCXIX).

Scribe B

231/ Bishop Girbert of Paris, Abbot Hugh of Saint-Germain of Paris and Hugh of Chaumont notify that the monks of Tiron have been given the wood of Jardy and all the property that belonged, half to the bishop of Paris and half to Hugh of Chaumont, the king's constable, who held it of the fee of the abbot of Saint-Germain, 1120, fol. LXIIr. Printed T1.51 (XXXII).

Scribe B

232/ Count Palatine Henry of Troyes notifies that he has given and conceded to the church of Tiron and Hugh, the Cistercian abbot, his brother, sixty arpents of agricultural land and sixty arpents of woods at Arable, half of his meadows at Dormans, a vineyard and use of the water within specified limits, 1156, fol. LXIIv. Printed T2.83. (See illustrations 3 and 4 )

Unidentified hand 2

233/ Notice that James of Dormans conceded to the monks of Tiron living at Fons d'Arable what his mother had given them, that is a measure of wine, undated, fol. LXIIv. Printed T2.19 (CCXLVIII). This act has also been entered in the cartulary by scribe B on fol. 77 r. (See act $n^{\circ} 283$ )

Unidentified hand 2

234/ Walter of Cortergei and Robert his son-in-law gave a tithe at Treslort, undated, fol. LXIIv. Printed T2.19 (CCXLVIII). Merlet has treated this act, which has both arabic and roman numbers assigned to it, as a continuation of $\mathrm{n}^{\circ} 233$. This act was also entered in the cartulary by scribe B on fol. LXXVIIr. (See act $n^{\circ} 284$ )

Unidentified hand 2

235/ Notice that Andrew of Baudemont conceded, and with the assent of his son Guy, gave to the monks of Tiron 2os. of the demesne rent at Barzy and Passy, two settlements between Chateau-Thierry and Dormans, undated, fol. LXIIv. Printed T1.92 (LXXIII).

Scribe B

http://www.unicaen.fr/mrsh/craham/revue/tabularia/print.php?dossier=dossier9\&file=07thompson.xml 
236/ Bishop Stephen of Paris notifies that he has given to the monks of Tiron whatever Pagan Bisol had held in the tithes and other property of the church of St Rémy of Fontenay, before he gave the property to the monks and he did so at the request of Galdricus of Hulmeio who had conceded it from his fee, undated but between 1124-42, fol. LXIIIr. Printed T1.80 (LIX).

Unidentified hand 16

237/ Notice that Pagan Bisol gives to the monks of Tiron whatever he has in the church of Fontenay, undated but after 1119, fol. LXIIIr. Printed T1.79 (LVIII).

Unidentified hand 16

238/ Bishop Joscelin of Soissons notifies that Gosbert of Dormans, his wife, Comitissa, and son James confirmed the gift they had made to the monks of Tiron at the place called Fons de Arabl, that is two carrucates of land, fields and wood, an arpent with nine nut trees and nine arpentsof meadow, done at Dormans, 1129, fol. LXIIIr. Printed T1.130 (CX).

Scribe B

239/ Manasses of Tournan and Beatrix, his wife, give to the monks of Tiron by the hand of Bishop Stephen of Paris (1124-1142) land they bought from their famulus Guiboldus and the land of Putoi. They also gave 3os. from the tolls of Tournan to light the church and other property. Three other benefactions are recorded, undated, fol. LXIIIv. Printed T1.119 (XCIX).

Scribe B

[No number] A settlement between the monks of Tiron and the nuns of Saint-Avit of Châteaudun is notified concerning tithes on the land which Ro[trou?] of Montfort gave to the monks of Tiron, undated, fol. LXIIIIr. Printed T1.218 (CXCII). Merlet dates this to 1135 , assuming that the bishop-elect of Le Mans, mentioned in the act, is Hugh of Saint-Calais, but gives no reason for choosing this particular bishop.

Scribe A

240/ Notice that Hugh of Glatigny gave to Saint Laurence and the monks living at L'Aunay 6d., undated, fol. LXIIIIr. Printed T2.79 (CCCVI).

Scribe A

241/ Notice that William of Fastiniis gave to the monks of the church of Saint Laurence at Le Gué de l'Aunay, the tithe of his fee in Vibraye, undated, fol. LXIIIIr. Printed T2.4 (CCXXX).

Scribe A

242/ Notice of an exchange between the monks of Tiron and Tescelinus Guerrer in which land at Vibraye was exchanged for land at Mons Fusnardus conceded in the chapter by Abbot William, undated, fol. LXIIIIv. Printed T2.72 (CCXCIX).

Scribe A 
243/ Notice that Hugh Amicus Bonus of Valeniis gave his brother, Theobald the hermit, land at the boundaries of La Loupe and Theobald assigned it to the monks of [Le Gué de l']Aunay, undated, fol. LXVr. Printed T1.235 (CCVII).

Scribe A

244/ Notice that William of Soizé and his mother Mathea gave to the monks of Tiron the land of Insule Gocelini, which is called Le Gué de l'Aunay, and everything that pertained to that land. It was conceded by the lord Rotrou of Montfort-le-Rotrou, who gave both banks to the monks to make a mill and as a fishery. Much later William gave a carrucate of land and Rotrou gave a carrucate of land, the wherewithal to make meadows, grazing for pigs, pasture for animals and use of woodlands for fuel and timber, undated, fol. LXVr. Printed T1.222 (CXCIV). A pancarte of the foundation of Le Gué de l'Aunay. Scribe A writes as far as 'et droco espechel', then unidentified hand 17 takes over, Scribe A resumes on fol. LXVv. This may be evidence for Scribe A as a senior figure in the scriptorium, who is training a younger monk.

\section{Scribe A and unidentified hand 17}

245/ Notice that Simon of Porco Mortuo gave to the monks of Tiron, a tithe of his lands in the parish of Tourny; William the priest of Tourny gave the lesser tithes which he used to take from lands and gardens of the monks; Robert Rex gave to the monks a measure of nuts, receiving 11s. from monk Ralf Tunsor; Gilbert Trohorit gave four acres of land at Tourny; Maurice the clerk of Fontenay and his mother Ascelina gave an acre of land adjoining our land at Faeio, undated, fol. LXVIr. Printed T1.214 (CLXXXVIII). This act is separated from the other entries relating to Tourny ( $\left.{ }^{\text {os }} 213-215\right)$. It seems to be another formulation of $\mathrm{n}^{\circ} 213$ and does not mention the participation of Archbishop Hugh of Rouen.

Scribe A

246/ Notice that Odo of Aco at his conversion gave himself and his possessions to the monks of Tiron and made his gift at the altar of Mary Magdalen of Croixval. His brother Peter conceded the gift and received four coins from the monks, undated, fol. LXVIv. Printed T1.237 (CCIX).

Scribe A

247/ Notice that Pagan Helinand and Hubert Salva Granum gave one carrucate of land to the monks of the holy saviour at Croixval with the approval of Grisegonella, count of Vendôme (1102-1139), Guy Turpin and Pagan du Val; Fromund Licho gave an arpent of meadow and half and arpent of land, for which the monks pay $3 \mathrm{~d}$. in rent; Hubert Salva Granum sold the monks of Croixval four arpents of land and meadow for the price of one cow and the monks pay $16 \mathrm{~d}$. in rent; Gifard sold the monks an arpent in the same place and land near the old mill for 2 s. and the monks pay $4 \mathrm{~d}$. in rent; Elizabeth, wife of Hubert Salva Granum, and Pagan Helinand gave the monks various plots of meadow and land; Gifard sold the monks three arpents of land for $7 \mathrm{~s}$. and the monks pay 8d. rent; Helgo of Caresmo gave the monks of Croixval an arpent of meadow; Fulcher de Pinellis, Pagan Helinand, Milsendis, his wife, and their sons, Hugh and Reginald, concede what he gave, undated, fol. LXVIv. Printed T1.93 (LXXIV). This pancarte describes the accumulation of the endowment at Croixval.

Scribe A 
248/ Notice that the monks of Croixval wished to buy land from Pagan Olere, but were unable to do so because the dean, Gerald, bought it first. They then made an arrangement with Gerald to purchase the land which would revert to the monks after his death, undated, fol. LXVIIr. Printed T1.166 (CXLI).

Scribe A

249/ Notice that Erenburgis of Aunay gives to the church of Tiron her son, Arnulf, to be made a monk, and all her land at Granri, and her husband Guy Berardus and son Robert of Aunay conceded it, undated, fol. LXVIIv. Printed T1.196 (CLXXVI).

Scribe A

250/ Notice that Sicilia, daughter of Guy Turpin and wife of Mathew of Trou, gives to the monks of Tiron 8s. each year on the feast of All Saints, undated fol. LXVIIv. Printed T2.51 (CCLXXXII).

Scribe A

251/ Notice that the monks of Lavardin delivered to the monks of Granri land situated near them to be cultivated for fifteen years and then returned to the monks of Lavardin. The latter monks will provide a quarter of the seed in return for a quarter of the harvest, 1128, fol. LXVIIIr. Printed T1.114 (XCII).

Scribe A

252/ Notice that Gervase son of Pagan of Versey and his mother, Breta, gave to the monks of Tiron land for four oxen in open country to build their place and the church of Saint Michael the archangel, together with the tithe of Valgalle, dated 1128; Fulk Piscis gave enough land for half a measure of seed; William Quarellus gave land for eight sestiers of seed; Albert of Gué Ramé, having been made a monk, gave land for seven sestiers of seed; Fulk of Chahenne and Drogo Custodiens Piras gave land for three sestiers of seed; Guiburgis, wife of Gaignard the standard bearer gave the tithe of the mill of Acheio; after several years William Quarrell gave land for two sestiers of seed; Robert of Brulio gave as much of his meadows as one man could cut in a day, later sections undated, fol. LXVIIIr. Printed T1.110 (LXXXIX). A pancarte.

Scribe A

253/ Notice that Gervase son of Pagan of Versey and his mother, Breta, gave to the monks of Tiron land for four oxen and the tithe of Valgalle, dated 1128; the witnesses of the gifts of William Quarellus, William of Gué Ramé, Fulk of Chahenne, Guiburgis, wife of Gaignard and Fulk Piscis are recorded, fol. LXVIIIv. Merlet does not print this version, but notes its existence.

Scribe A

254/ Notice that Haois of Montfaucon has given to Abbot William and the convent of monks of Tiron the land of Sainte-Sabine, conceded by Fulk of Montfaucon, 1128, fol. LXIXr. Printed T1.112 (XC). This act is preceded by two signa labelled Signum Haois and Signum Fulconis. Scribe A wrote as far as 'Ricardo de bosco'. Unidentified hand 18 wrote from 'Willelmo de soure', which shows some similarities with that of Scribe B, but lacks his consistency; similar lapses, however, are found to a lesser extent in the stint 
that includes fol. LXXIIr, which is more obviously that of Scribe B. The deterioration of B's hand on fol. IIII XXIIIr might also suggest that this unidentified is, in fact, that of Scribe B.

Scribe A and unidentified hand 18, who could be scribe B

255/ Notice that Elisendis, known as Pagana, a citizen of Le Mans, was veiled by the monks of Tiron on her deathbed, and gave them vines in Coulaines with the approval of her sons, who will pay the monks 1oos. if they wish to recover the vines, undated, fol. LXIXv. Printed T2.18 (CCXLVI).

Scribe B

256/ Notice that Odo corversarius gave to the church of the Holy Trinity of Tiron a measure of wine every year on condition that the wine was shared between the monks of Tiron and the monks of Montaillé, undated, fol. LXIXv. Printed T2.78 (CCCV).

Scribe B

257/ Notice of the offerings which were made through the hand of the monk, Mark: Dodoin of Bomboio gave the place, Bréau, where the monks had gathered and a ploughland nearby, the use of his woodland for fuel, timber and pasturage of pigs without payment and on his deathbed he conceded the tithes on all his lands, given by the faithful; Odo fitz Rolland gave the land of Becacaria; Cecilia Bona Filia gave a tithe; Ernald and Fulcho gave land next to Bréau; Fulcho gave further land in return for 16s.; Garnerius conceded whatever tithes the Bonboii had given; Elizabeth, wife of Alroll, gave on her deathbed two iugera of arable land; William of Monte Leobovio gave another five iugera of land at Regentum; later Amelina and Ilduin her son gave three iugera at Iboscellum, all undated, fol. LXXr. Printed T2.51 (CCLXXXIII). The Bréau pancarte.

Scribe B

258/ Notice that Erard of Curte Ostranni, his wife and sons gave to the monks dwelling at Saint Mary of Bréau a wood and land at Calumpniam; William of Monte Leti Bovis and his wife gave two fields, undated, fol. LXXv. Printed T2.32 (CCLXIII).

Scribe B

259/ Notice that Guy of Menevilla gave to the monks of Tiron a tithe of the mills at Maen, 1129, fol. LXXIr. Printed T1.131 (CXI).

Scribe B

260/ Notice that Adam nepos of Drogo Brochart of Varenna gave to the monks during his lifetime all the property known as La Couture in the parish of Mereil. Drogo, the lord of this land, conceded it for 50s. and inclusion in the prayers of Tiron, and the monks were conceded two arpents to hold freely for the construction of their building, undated, fol. LXXIr. Not printed by Merlet but mentioned in a footnote to $\mathrm{n}^{\circ} 261$.

Scribe B

261/ Notice that Adam nepos of Drogo Brochart of Varenna gave to the monks during his lifetime all the property known as La Couture in the parish of Mereil. Drogo, the

http://www.unicaen.fr/mrsh/craham/revue/tabularia/print.php?dossier=dossier9\&file=07thompson.xml 
lord of this land, conceded it for 50s. and inclusion in the prayers of Tiron, and the monks were conceded two arpents to hold freely for the construction of their building. This was disputed by Simon, son of Beroard, who took the monks' oxen, but it was settled at Pithiviers in the cloister of the Cluniac house there, with a payment of 40 ., undated, fol. LXXIr. Printed T1.183 (CLX).

Scribe B

262/ Notice that Erard Curciaci and his wife Hildeardis gave to the abbot and monks of Tiron a tithe of their holding at Pipponvillari and placed their gift on altar of the cell at Coutures when the first mass sung there, undated, fol. LXXIIr. Printed T1.245 (CCXVIII).

Scribe B

263/ Notice that Drogo Brochard, Egidia his wife and Robert their son give to the abbot and monks of Tiron wood and land at Choellia, undated, fol. LXXIIr. Printed T2.29 (CCLIX).

Scribe B

264/ Notice that Drogo Brochard concedes to the monks of Tiron half land at Couture, which his nephew Adam gave them, and recently he gave a carrucate of land at the same place after his death; he gives the wood of Coella with the land in which it is situated and has received from the monks 5s. and a measure of wheat and will receive 12d. annually as rent for the wood, undated, fol. LXXIIr. Printed T2.30 (CCLX). This entry refers to $n^{\circ} 261$.

Scribe B

265/ Froger of Marulio and his wife Osanna gave to the monks of Tiron all their land of Mauriolo with consent of his lady, Oda and her son Reginald, in whose fee it was; Oda and her son received from the monks of Tiron 40s. in orléanais money and Oda's brother, Reginald, 20s., 1138, fol. LXXIIv. Printed T1.248 (CCXX).

Scribe B

266/ Abbot William of Tiron notifies that Gaudinus, son of Theobald Harvey, has withdrawn his claim to land near Mareuil, undated, fol. LXXIIv. Printed T1.238 (CCX).

Unidentified hand 3

267/ Notice that Manasses of Tournan had conceded 3os. to light the church of Saint Ouen, which he subsequently denied, and then acknowledged in the presence of Abbot William, undated, fol. LXXIIIr. Printed T1.198 (CLXXVIII). See act n ${ }^{\circ} 239$ for the first gift.

Scribe B

268/ Notice that Walter of Villa Meion gave to the monks at the church of Saint Ouen four arpents, for which they received six coins a year; Fulbert also gave to the monks of Tiron all his land at Foveas and received sixteen sestiers of wheat and other items, undated, fol. LXXIIIr. Printed T1.167 (CXLII).

Scribe B 
269/ Notice that Guy of Villanis rescinded to the monks four coins, which the monks owed him for a meadow, and gave them six coins annually; undated, fol. LXXIIIr. Merlet prints this act as part of $n^{\circ} 268$.

Scribe B

270/ Notice that Peter Magister rescinded three measures of oats, which he used to have from the meadows of Saint Peter, undated, fol. LXXIIIr. Merlet prints this act as part of $n^{\circ} 268$.

Scribe B

271/ Notice that Adam of Armentrecis gave to the monks of Tiron, living at Saint-Ouen, all the meadow he held at Villam Meion and received 4os. He rescinded to them twelve coins due for rent each year; Adam also gave to the monks land next to Villam Meion and received 1os., undated, fol. LXXIIIr. Printed T1.198 (CLXXIX).

Scribe B

272/ Notice that the meadow at Villam Meion, as formerly held by Walter of Villa Meion was conceded to the monks of Saint Ouen by Gilbert, once the king's butler, his wife Eustachia and son, Guy and Manasses, and recently by their sister Aloisa, undated, fol. LXXIIIv. Printed T1.239 (CCXI).

Scribe B

273/ Gervase of Châteauneuf-en-Thimerais, Margaret his wife and their sons, Hugh and Hervey notify that William of Pommereio gave to the monks of Tiron living at Saint Bartholomew of Vieux-Charencey half his land in the parish of Saint-Maurice. Goherius of Morvilla, William of Chavigneo and William of Nemore conceded it. The monks of Tiron gave Gervase $£ 12$ in angevin money, 1202, fol. LXXIIIIr. Printed T2.120 (CCCXLIII).

A $13^{\text {th }}$-century hand

274/ Notice that William fitz Isnard of Charencey gave to the monks of Tiron land at Virgereiis and claims against it were waived, undated, fol. LXXIIIIv. Printed T2.69 (CCXCV).

Scribe B

275/ Notice that Gerald fitz Fulbert, at the point of his conversion, gave to the monks of Tiron land for two oxen and tithes in Charencey, and all his tithes, except those of the carrucate which the monks of Saint-Père of Chartres held, undated but before 1149, fol. LXXIIIIv. Printed T1.168 (CXLIII).

Scribe B

276/ Notice that Robert Picard gave Saint Mary, Saint Maurice and the monks of Tiron all that he had in fee of Charencey and the monks promised to give 3os. to Hersendis, his daughter, whether she married or entered religion. William of Boissey, the lord of the fee, disputed it until his brother Fulbert was beset with great trouble, undated, fol. LXXIIIIv. Printed T1.239 (CCXII). Merlet believed this act to be incomplete. It is the last act on the last of the gatherings that are covered by the cartulary's contents pages.

Scribe B

http://www.unicaen.fr/mrsh/craham/revue/tabularia/print.php?dossier=dossier9\&file=07thompson.xml 
277/ Notice that Manasses of Tournan gave to the monks of Tiron 30s. from the rents of Tournan and later withheld them for a long time. When stricken by illness at the advice of the monks he restored them and the monks gave him four measures of wine, undated, fol. LXXVr. Printed T1.197 (CLXXVII). See acts n 239 and 267. Half a leaf of parchment has been removed here.

Scribe B

278/ Notice that Tescelinus, his son Dainbert and wife, Amica, Fulco de Taroent, his wife, Amelina, and son Joscevin, and Gaubert and his wife, Mabel, gave the place of Secreu to the church of Tiron, together with as much land as can be ploughed by four ploughs, tithe of land, pasnagium and forestagium from the wood and Reginald of Campovalum conceded the gifts, undated, fol. LXXVv. Printed T2.18 (CCXLVII).

Scribe B

279/ Notice that Baldwin de Villa Fluis, Mensendis his wife and their children conceded to the monks of Tiron who had gathered at Raincy as much of the land that was uncultivated when they arrived as would amount to a carrucate and gave them what they needed from his woodlands, undated, fol. LXXVIr. Printed T1.168 (CXLIV).

Scribe B

280/ Notice that William of Saint-Cheron gave his whole fee to the monks of Holy Trinity of Tiron; William's sons retained 2 s. rent from the land which the monks paid every year and conceded the tithe of all the lands that the monks cultivated themselves, undated, fol. LXXVIv. Printed T1.169 (CXLV).

Scribe B

281/ Notice that Ralph of Saint-Cheron gave to the monks of Tiron all the land he held of the monks, which William of Saint-Cheron had formerly held and the monks paid $£ 4$, undated, fol. LXXVIv. Printed T1.252 (CCXXIV).

Scribe B

282/ King Louis [VII] of France, duke of the Aquitanians gives notice that he has conceded to the monks of Tiron from his royal property a settler at Meudon free from any taxation and services, undated but between 1137 and 1152, fol. LXXVIv. Printed T1.94 (LXXVI).

An archaising hand that is later than late- $12^{\text {th }} / 13^{\text {th }}$-century script it is imitating

283/ Notice that James of Dormans conceded to the monks of Tiron living at Fons d'Arable the property that his mother had given, including a measure of wine, a cartload of hay to be rendered annually, undated, fol. LXXVIIr. Printed T2.19 (CCXLVIII).

Scribe B

284/ Walter of Cortergei and Robert his son-in-law gave a tithe at Treslort, undated, fol. LXXVIIr. Printed T2.19 (CCXLVIII). Merlet treats this act as a continuation of $\mathrm{n}^{\circ} 283$.

Scribe B 
[Unnumbered] Two acts in hands of late $15^{\text {th }}$ - or early $16^{\text {th }}$-century date

285/ Bishop Vulgrin of Angers (1124-1149) asks Abbot William of the Tironensian monastery, at the request of Gerald, the lord of Montreuil-Bellay, to create an abbey at Asnières, where the monks William has sent have been serving God, undated, fol. LXXVIIIr. Printed T1.121 (XIX).

Scribe B

286/ Gerald Berlay of Montreuil-Bellay gives and concedes to the monks of Tiron four landholdings at Asnières and as much wood as a donkey may carry, undated, fol. LXXVIIIr. Printed T1.35 (XIX).

Scribe B

287/ Chotard, his children and wife Beatrix write to the congregation of Tiron informing them that he has given to the abbot and brothers 10os. each year in mid March, undated, fol. LXXVIIIr. Printed T1.134 (CXIII).

Scribe B

288/ Notice that James, Chotard's armiger, conceded his house to the brothers of Notre-Dame of Tiron, by the hand of the lord Gerald, undated, fol. LXXVIIIv. Printed T1.135 (CXIV).

Scribe B

289/ Notice that Geoffrey lord of Doué ... Two and a half lines of act nº 291.

290/ A chirograph notifies that the monastery of Asnières, founded Gerald Berlay, has sought and been granted an abbot from the lord William and all the convent. There are provisions for the election of the abbot and various disciplinary matters, 1131, fol. LXXVIIIv. Printed T1.131 (CXII). Merlet reads the date of this act as 1139 and corrects it to 1129. A better reading is 1132 with a stroke through the final figure, perhaps indicating 1131 .

Scribe B

291/ Geoffrey lord of Doué assigned all his land of Ferrières to the brothers of Tiron and conceded whatever his men gave from their holdings. Viscount Aimery of Thouars and his wife Agnès assigned whatever they possessed at Ferrières to the brothers of Tiron and the viscount conceded whatever was granted from his holdings; Aimery of Torneria and his wife Vilena, gave two holdings of land; the dispute between the monks of Ferrières and Pagan Cabut was heard before Viscount Aimery of Thouars and the Viscountess Agnes, undated fol. LXXIXv. Printed T2.170 (CXLVI). A pancarte associated with the settlement at Ferrières. Merlet has divided this into its constituent parts: Viscount Aimery's act is printed as T1.171 (CXLVII); Aimery of Torneria is printed as T2.21 (CCL); and the dispute as T1.172 (CXLVIII).

Scribe B

292/ Notice that Andreas Begonus and his wife conceded themselves and all their property to the monks of Tiron at Ferrières before Savaric of Mauléon and the 
act details the rents due from this property, undated, fol. IIII ${ }^{\mathrm{Xx}} \mathrm{r}$. Printed $\mathrm{T} 2.53$ (CCLXXXIV).

293/ We, the Goscelin brothers give to a monk and his fellows the fee that they have in two mills, undated, fol. IIII ${ }^{\mathrm{XX}}$ r. Printed T1.199 (CLXXX).

Scribe B

294/ Pagan de Vallibus, Beloth de Claris Vallibus and John de Tuschia give to the monk Bernard de Murciaco two parts of the land between the wood near to Saint-Médard and the wood of Lapelocheria, which divided into three parts we gave to three hermits: to Bernard himself, to Maurice and to another, undated, fol. IIII ${ }^{\mathrm{XX}} \mathrm{V}$. T2.20 (CCXLIX).

Scribe B

295/ Laethoth, his brother, Airaldus, Jobertus of Chabannis, Hugh of Tariee, Maentia and their children give to Bernard and his fellows land at Pozels, vines, meadow, a copse, lodgings and an orchard, undated, fol. IIII ${ }^{\mathrm{Xx}} \mathrm{V}$. Printed T2.70 (CCXCVI).

Scribe B

296/ Notice that Ama of La Forêt gave to the monks of Tiron a land holding; a quartarium of land which Saldebrel had in mortage and Oliver of Parthenay redeemed for the monks; and in her last illness she gave bread sales in the market of La Forêt and a carrucate of vines. After her death her son gave all the land between the two roads at Le Theil, half in exchange for the 20 sestiers of wheat his mother received as a gift, undated, fol. IIII ${ }^{\mathrm{Xx}} \mathrm{V}$. T1.6o (XL). A pancarte associated with the settlement at La Forêt-sur-Sevre. Merlet has divided this into its constituent parts: Notice that William of Escollan gave himself to the monks of Tiron and a borderia called Sichateria. When this was challenged by William de Dillonio and his brother, Gerald the monk gave them 20s. and the monks gave $4 \mathrm{~d}$. annually, undated, fol. IIII ${ }^{\mathrm{XX}} \mathrm{Ir}$. Printed T2.219 (CCLI). Notice that Peter Girald, brother of William of Escollan gave himself to the monks of Tiron and a borderia of land in two places, undated, fol. IIII ${ }^{\mathrm{XX}} \mathrm{Ir}$. Printed T2.22 (CCLII).

Scribe B

297/ Notice that Amaury of Fai and his son Aimery gave to the church of St Mary Magdalen of Reuzé rights over the sale of bread sale at Faye, fol. IIII ${ }^{\mathrm{XX}} \mathrm{Iv}$. Printed T2.22 (CCLIII).

Scribe B

298/ Notice that William of Colonia and his wife Milesendis give to the church of Reuzé a vineyard which has a rental of 2 d., undated, fol. IIII XX Iv. Printed T2.54 (CCLXXXV).

Scribe B

299/ Notice that Geoffrey of Orchis with the assent of his brother Ralph and nephew, Burchard, gives to the church of Saint Mary Magdalen of Reuzé seven iugera between Reuzé and Orches, undated, fol. IIII ${ }^{\mathrm{XX}}$ Iv. Printed T2.33 (CCLXV).

Scribe B 
30o/ Count Geoffrey of Anjou (1129-51) conceded the gift of father, Fulk, who was then king of Jerusalem to the abbot and monks of Tiron, and confirms the mill, made by Brother Guy the prior, the lake, wood and whatever was acquired there for the salvation of his soul and those of his wife and children, undated but 1134-1142, fol. IIII ${ }^{\mathrm{XX}}$ Iv. Printed T1.189 (CLXV). The name of the possession is not recorded, but the entry is made among those for Reuzé.

Scribe B

301/ Boso of Boslantot concedes to the monks of Tiron dwelling at Reuzé land, a place to build a mill, lake, fishery, weir and whatever they build on the weir, undated, fol. IIII ${ }^{\mathrm{XX}}$ Iv. Printed T2.32 (CCLXIV).

Scribe B

302/ Notice that Garsirius and his brother Goscelinus and son gave and conceded the place called Sept Faux to the monks of Tiron, undated, fol. IIII ${ }^{\mathrm{Xx}}$ IIr. Printed T2.55 (CCLXXXVI).

Scribe B

303/ Archbishop Hugh of Tours writes to Abbot William of Tiron and the convent, thanking them for establishing an abbey at Luzé, which the archbishop takes under his protection and concedes their customs, saving the rights of the church of Tours, undated, fol. IIII ${ }^{\mathrm{XX}}$ IIr. Printed T1. 253 (CCXXV).

Scribe B

304/ Notice that the monastery of Luzé, which was once a cell of Holy Trinity of Tiron, and has been constituted an abbey at the request of Brice of Le Chillou. Brice and his brother, Adelelmus, have conceded that the abbey shall be free, that the abbot shall be elected at Tiron and will acknowledge Tiron as the mother house, 1138, fol. IIII ${ }^{\mathrm{XX}}$ IIv. Printed T1.249 (CCXXI).

Scribe B

305/ Brice of Le Chillou concedes to the monks of Tiron the place of Saint Michael of Luzé, which he had given to the monk, Robert. He gives as much land as 24 oxen may plough and, if the abbot is prepared to make an abbey, sufficient for 30 oxen. Land for the establishment of vines and gardens is also given and access to woodland, undated, fol. IIII ${ }^{\mathrm{XX}}$ IIIr. Printed T1. 240 (CCXIII).

Scribe B

306/ Notice that Goslen of Corseth conceded to the monks of Tiron an island in the Loire, on which the chapel of Saint Nicholas is situated. He gave land off the island and as much meadow as two men can cut in a day. Ralph of La Guerche gave to the church of Saint Nicholas the tithe of the island, undated, fol. IIII ${ }^{\mathrm{Xx}}$ IIIv. Printed T2.34 (CCLXVI).

Perhaps Scribe A

307/ Conan, count and duke of Brittany gives to the monks of Tiron the toll of Pont Rousseau and a fishery. This gift he has made to buy butter and fish and was made

http://www.unicaen.fr/mrsh/craham/revue/tabularia/print.php?dossier=dossier9\&file=07thompson.xml 
when he was in the chapter of the Tironensian monks on his way to Vézelay, 1132, fol. IIII ${ }^{\mathrm{XX}}$ IIIIv. Printed T1.195 (CLXI).

Perhaps Scribe B

308/ Notice that Duke Conan of Brittany and Hermeniardis his mother gave to the monks of Tiron Pont Russeau, the road, and $2 \mathrm{~d}$. for each vehicle. The count gave them three food rents for each day he was at Nantes and timber for their use, undated, fol. IIII ${ }^{\mathrm{XX}} \mathrm{IIIIv}$. Printed T1.244 (CCXVI).

Perhaps Scribe B

309/ Notice that Jeremias give to God, Abbot Bernard of Tiron and the monks six carrucates at Mellerets and all the meadow they can make; more recently all his meadow at Arrou, a site to make a mill and water to fish; all his woodland for fuel and building timber, pasture for animals and flocks, grazing for their pigs and those of their men, undated but before 1116, fol. IIII ${ }^{\mathrm{Xx}} \mathrm{Vr}$. Printed T1.16 (V).

Late $12^{\text {th }}$ - or early $13^{\text {th }}$-century hand

310/ Notice that the dispute between the monks of Tiron and Nicholas of Brueria concerning the settlement at Mellerets was heard at Brou and it was resolved that the monks would have four carrucates of land at Mellerets, besides those of their dwelling, as they had always had. Nicholas conceded fuel for them and the monks of Brou, and they would receive timber for their dwellings; they and their settlers would have common pasture outside the hedges, undated, fol. IIII ${ }^{\mathrm{XX}}$ Vr. Printed T1.96 (LXXVII).

$13^{\text {th }}$-century hand

311/ Abbot Stephen [II] of Tiron notifies that he has given and conceded with the assent of the whole chapter their land of Chardonnelles, situated in the parish of Pré-Nouvelou, by arpent to the following men: a list follows. Rents are to be delivered to the monks or their agent every year at Chodreium on the eve of All Saints, 1264, fol. IIII ${ }^{\mathrm{XX}}$ Vv. Printed T2.179 (CCCLXXXVIII).

$$
13^{\text {th }} \text {-century hand }
$$

312/ Archbishop Hugh of Rouen notifies Abbot William of Tiron that he concedes to him the church of Saint Mary of Bacqueville which William Martel had restored to the archbishop, and the archbishop itemises the endowment, 1133 , fol. IIII ${ }^{\mathrm{XX}} \mathrm{VIr}$, written in an archaizing hand of the $15^{\text {th }}$ century. Single sheet original AD Seine-Maritime D 194. Printed T1.203 (CLXXXIII).

A single $15^{\text {th }}$-century hand

313/ William Martel with the assent of his mother, wife and brother gave the church of the Holy Saviour at Tiron the church of Saint Mary of Bacqueville and its endowment, and he has given recently from his own demesne twenty acres of land, assorted wood and a garden, tithes of his rents in Normandy and England, tithe of his home-grown food and two measures of wine at Rouen. He conceded whatever his men might give in his fee and he extended the endowment elsewhere, 1134, fol. IIII ${ }^{\mathrm{XX}}$ VIIr. Printed T1.216 (CXC).

A single $15^{\text {th }}$-century hand 
314/ William Martel notifies that he has given and conceded to Saint Mary of Bacqueville and the monks of Tiron serving God there the land that his vavassors gave to the church after the death of his grandfather until the day he took the cross; a list follows. Recently he has conceded to the monks the chapel of Saint Leonard of Bacqueville with all its property and the monks may appoint the chaplain until William can provide a sum of 6os. sterling, 1188, fol. IIII ${ }^{\mathrm{Xx}}$ VIIv. Printed T2.108 (CCCXXXII).

A single $15^{\text {th }}$-century hand

315/ William Martel notifies that he has confirmed to them all the gifts of his grandfather, William Martel, with the assent of his mother, wife, children and brothers; a list follows, 1193, fol. IIII ${ }^{\mathrm{XX}}$ VIIIr. Printed T2.113 (CCCXXXVIII).

A single $15^{\text {th }}$-century hand

316/ Archbishop Rotrou of Rouen confirms the church of Saint Mary of Bacqueville with all its appurtenances to the monks of Tiron living there, undated but 1164-1183, fol. IIII ${ }^{\mathrm{XX}}$ VIIIv. Printed T2.97 (CCCXXV).

A single $15^{\text {th }}$-century hand

317/ William Martel, knight, lord of Bacqueville and chamberlain to the king notifies that on the resignation of Giles d'Estouteville from the chaplaincy of Saint Leonard's in his castle at Bacqueville he has presented Robert of Ynarvill to the archbishop of Rouen, but the presentation has been challenged by the prior of Bacqueville, who asserts that it belongs to him and William has passed it to him on this occasion, 1401, fol. IIII ${ }^{\mathrm{XX}} \mathrm{IXr}$. Printed T2.208 (CCCCXII).

A single $15^{\text {th }}$-century hand

318/ Notice that Alberic of Milicie gives and concedes, on the occasion of his son's reception into the congregation of Tironensian monks, all the land of Montaillé and the men living there, which came into the hand of King Louis from the forfeit of Gilbert, lord of Montaillé and was given to Alberic. He also gives and concedes the fee of Aunay, 1101, fol. IIII ${ }^{\mathrm{XX}} \mathrm{IXv}$. Printed T1.65 (XLVI). A single archaizing hand has added three acts on Montaillé, see $\mathrm{n}^{\text {os }} 210$ and 224. The date plainly indicates that this act is a confection and calls the others into question.

Late $15^{\text {th }}$ - or early $16^{\text {th }}$-century hand

319/ Pope Eugenius III takes into his protection the monastery of Tiron, itemising and confirming all its possessions, 1147, fol. IIII ${ }^{\mathrm{XX} X r}$. Single sheet original ADEL H 1378. Printed T2.6o (CCXCI), which differs significantly from the cartulary version printed as $\mathrm{T}_{2} .63$ (CCXCII).

Unidentified hand 19

$320 /$ Notice that Erard of Villabun, wanting to go the Jerusalem, gave the monks of Tiron a measure of wheat at his mill of Belvetum, undated, fol. IIII ${ }^{\mathrm{Xx} X I v}$. Printed T2.56 (CCLXXXVIII).

Unidentified hand 20

http://www.unicaen.fr/mrsh/craham/revue/tabularia/print.php?dossier=dossier9\&file=07thompson.xml 
321/ Notice that Ralph of Bolerio, father of Alice of Fulfriaco, and Peter Maleit gave to the monks of Tiron the chapel of the Holy Sepulchre at Montgé; Adam and Alice of Fulfriaco gave their part of the ploughed land at Montgé; Ralph of Ginbriaco and his brother Pagan gave the land of Cooli and received 3os. from the monks; Hubert of Monte Jonis gave six arpents of uncultivated land; and Walter Haiz of Creciaco gave the part which he had, undated, fol. IIII ${ }^{\mathrm{XX} X I v}$. Printed T2.55 (CCLXXXVII).

Unidentified hand 21

322/ Notice that William of Campo Floris gave to Abbot Bernard of Tiron his own land near Cohardons and the wood in which the church of Saint Mary Magdalen was built. It was free from all customs and all the men on the land were to be from free all secular exactions. Later he gave tithes of his mill, of the bread of his household, of his vineyard, of the payments of his pasnagium, his part of the tithe of Mortagne, and the wood of Clareio. He gave his forest for the monks to build and repair their buildings, and meadow; Walter of Roseio gave himself to Abbot Bernard and his land at Fons Garnerii and meadow and tithe; William Anglicus gave his tithe of Nesement to the same abbot along with others from the fee of William of Campo Floris; Gerald Revel gave a tithe of the bread of his household, undated, fol. IIII ${ }^{\mathrm{XX} X I I r}$. Printed T1.20 (IX). A pancarte for Cohardons.

Perhaps unidentified hand 20

323/ An account of foundation of Saint-Sulpice-en-Pail covers its donation by Hugh of Saint-Aubin to Tiron, along with two parts of the tithes and primitias, which his predecessors had held, and relations with members of the local elite, undated, fol. IIII ${ }^{\mathrm{XX}}$ XIIv. Printed T2.23 (CCLIV).

Unidentified hand 22

324/ Dean Geoffrey of Dol and the rest of the chapter conceded the church of Plerguer to the church of Le Tronchet by the hand of Abbot Stephen [I] of Tiron, undated, fol. IIII ${ }^{\mathrm{XX}}$ XIIIr. Printed T2.87 (CCCXIV).

Unidentified hand 22

325/ Brother John, abbot of Tiron (c. 1277-1297) writes to the abbot of Saint-Calais, undated, fol. IIII XXXIIIv. Not printed by Merlet. This act is indecipherable in places.

$13^{\text {th }}$ or $14^{\text {th }}$-century hand 


\section{Illustrations}

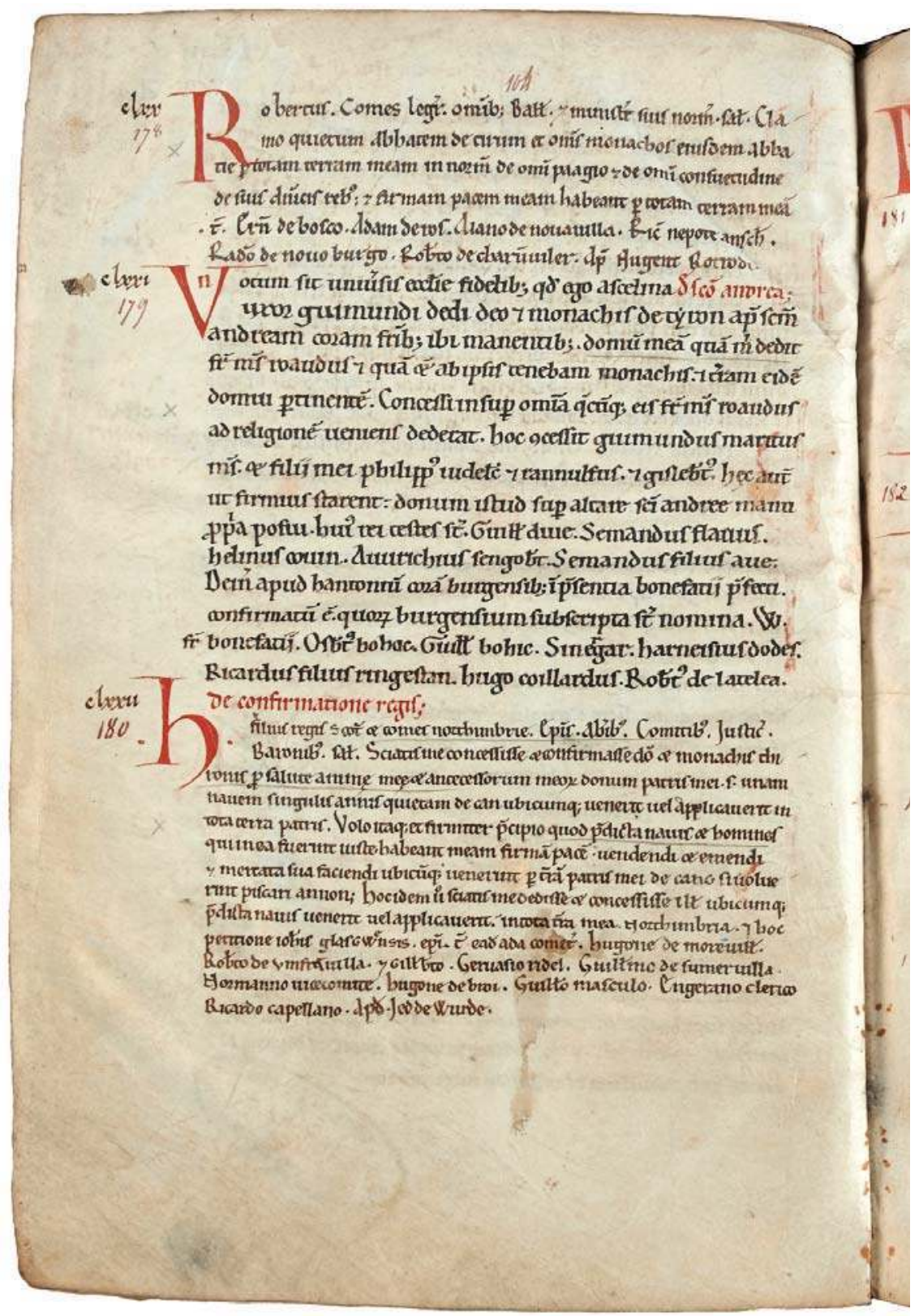

Illustration 1: Chartres, Arch. dép. Eure-et-Loir, H 1374, the cartulary of Tiron, fol. XLVIIIv. Scribe B has written the first and third acts and Scribe A has written the middle act (cl. Conseil général d'Eure-et-Loir). 


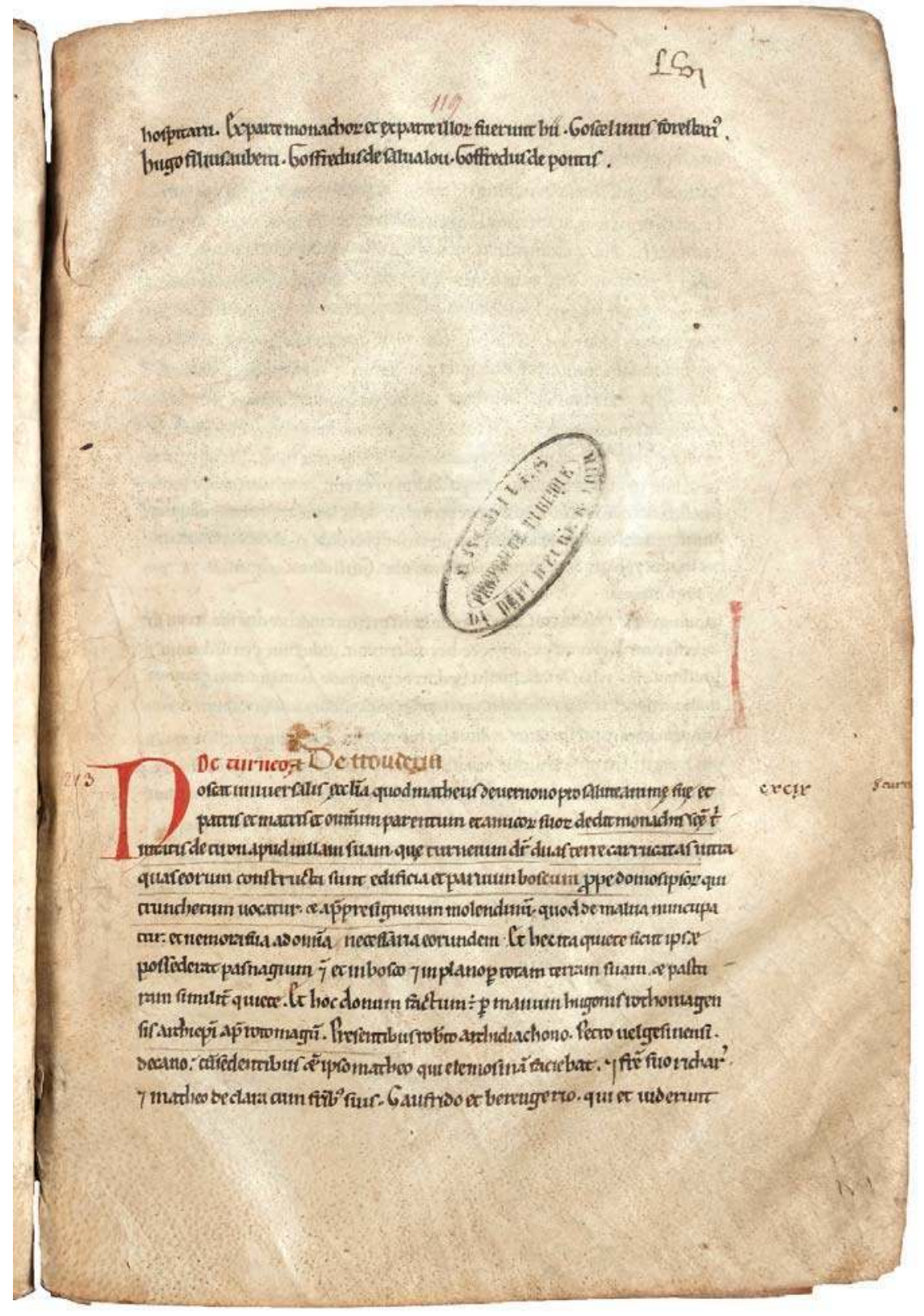

Illustration 2: Chartres, Arch. dép. Eure-et-Loir, H 1374, the cartulary of Tiron, fol. LVIr. Scribe B leaves space on the parchment for entries to be added (cl. Conseil général d'Eure-et-Loir). 


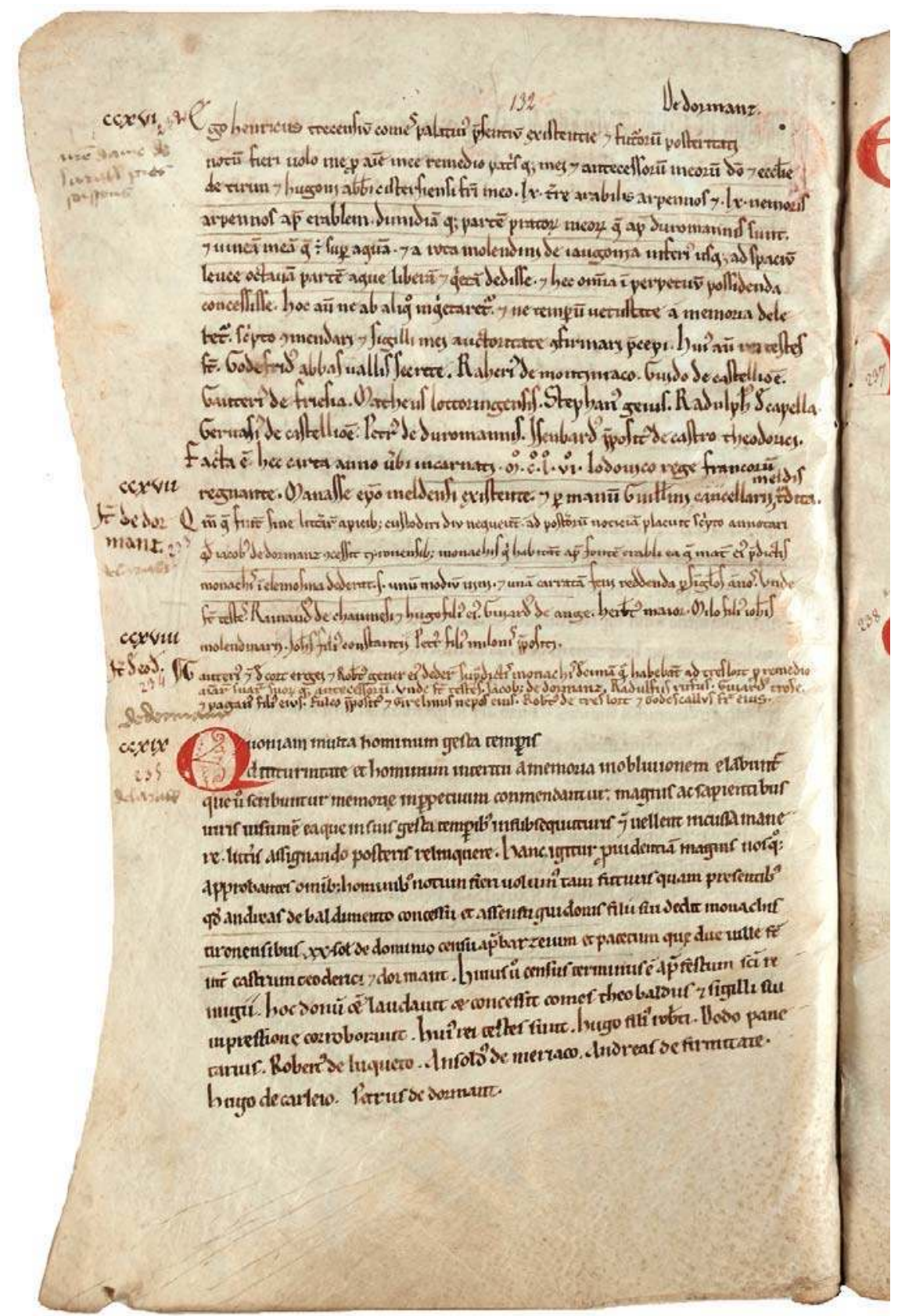

Illustration 3: Chartres, Arch. dép. Eure-et-Loir, H 1374, the cartulary of Tiron, fol. LXIIv. Acts $\mathrm{n}^{\circ} 232$ (roman $\mathrm{n}^{\circ}$ ccxvi) 233, 234 have been added to the text after 1156 by the unidentified hand 2 . Scribe $B$ had already written $n^{\text {os }} 233$ and 234 in another place in the cartulary (cl. Conseil général d'Eure-et-Loir). 


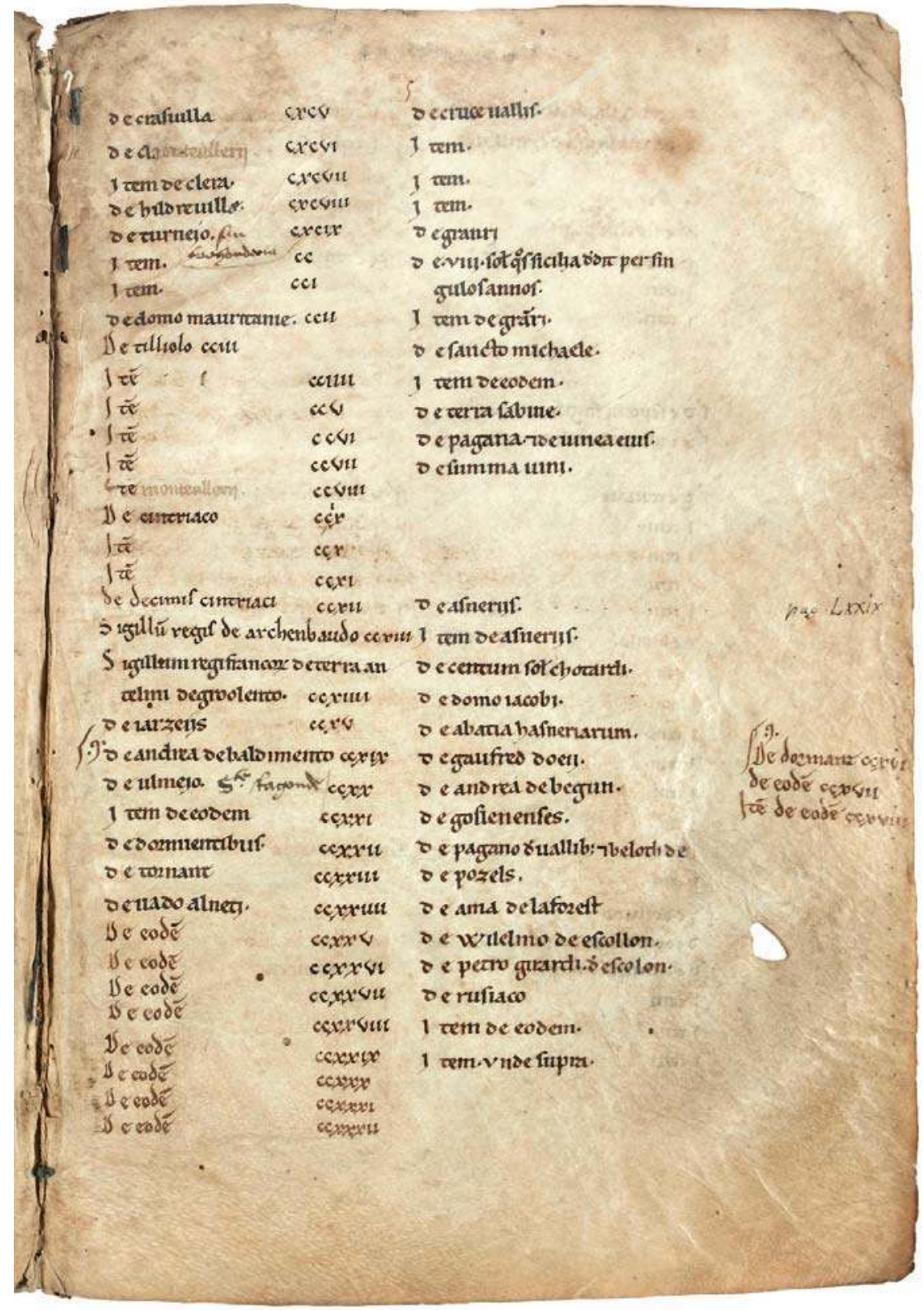

Illustration 4: Chartres, Arch. dép. Eure-et-Loir, H 1374, the cartulary of Tiron, fifth page of the contents table. Acts $n^{\text {os }}$ ccxvi to ccxviii, shown in Illustration 3 , have been added to the contents (cl. Conseil général d'Eure-et-Loir). 